\title{
The Intervening Role of Social Integration in the Effect of Education on Subjective Mental Health
}

\author{
Jacqueline Kroh \\ Leibniz Institute for Educational \\ Trajectories (LIfBi)
}

\author{
Sebastian Prechsl \\ Friedrich-Alexander-Universität Erlangen- \\ Nürnberg
}

This is a preprint version of a publication in Research in Social Stratification and Mobility.

Please cite as follows:

Kroh, J., Prechsl, S. (2023). The Intervening Role of Social Integration in the Effect of Education on Subjective Mental Health. Research in Social Stratification and Mobility, doi: $\underline{10.1016 / j . r s s m .2023 .100786}$

\section{Contact details}

Dr. Jacqueline Kroh

Leibniz Institute for Educational Trajectories

(LIfBi)

Wilhelmsplatz 3

D-96047 Bamberg

Germany

Email address

jacqueline.kroh@lifbi.de

ORCID

https://orcid.org/0000-0003-4938-4482
Dr. Sebastian Prechsl

School of Business, Economics and Society

Friedrich-Alexander-Universität Erlangen-

Nürnberg

Findelgasse 7/9

D-90402 Nürnberg

Germany

Email address

sebastian.prechsl@fau.de

ORCID

https://orcid.org/0000-0001-9033-7317 


\title{
The Intervening Role of Social Integration in the Effect of Education on Subjective Mental Health
}

\author{
Jacqueline Kroh \\ Leibniz Institute for Educational \\ Trajectories (LIfBi)
}

\author{
Sebastian Prechsl \\ Friedrich-Alexander-Universität Erlangen- \\ Nürnberg
}

\begin{abstract}
This paper contributes to the literature examining the interplay of education, social integration, and mental health. Based on social network theories, we argue that social integration plays a role in explaining the link between education and mental health. Using data from the German Panel Study Labour Market and Social Security (PASS) (observation period: 2006/2007 to 2018), our sample comprises 15,863 individuals. We use panel regression models to analyze the association between education and the probability of reporting at least good mental health. Based on mediation analysis techniques, we investigate the mediating role of strong and weak ties in this relationship. Results show that overall social integration, the number of close friends and relatives, and memberships in voluntary associations partly explain the link between education and mental health.
\end{abstract}

\section{Keywords}

Mental health inequalities, education, social integration, social networks, mediation analysis

\section{Acknowledgements}

The authors would like to thank Michael Gebel, Guido Heineck, Corinna Kleinert, Gerhard Krug, and the two anonymous reviewers for valuable suggestions and comments. We also thank the members of the Bamberg Graduate School for Social Sciences, the colleagues of the Chair for Economics, esp. Empirical Microeconomics of the University of Bamberg, and the discussants and participants at the ISA RC28 spring meeting 2021 and the DGS spring meeting 2020 of the sections "Soziale Ungleichheit und Sozialstrukturanalyse" and "Bildung und Erziehung". We thank all participants for their input. Our Stata code is publicly and permanently available at https://osf.io/98g4p/. Access to the scientific use file of the panel study 'Labour Market and Social Security' (PASS) can be requested at the research data center of the Institute for Employment Research (IAB).

\section{Funding}

The authors received no financial support for the research, authorship, and/or publication of this article. 


\section{Introduction}

Educational inequalities in mental health are a well-established phenomenon and individuals with lower levels of education tend to be at higher risk for poor mental health. This holds true for different countries and mental health indicators (Fryers et al., 2003; Halpern-Manners et al., 2016). For example, studies conducted in Australia, the UK, the US, and the Netherlands report that adults with a maximum of 11 years of schooling are more than twice as likely to suffer from an anxiety disorder and have a higher 12-months prevalence of experiencing mood disorders, such as depression. In addition, they demonstrate a higher prevalence of affective disorders in individuals who have obtained at most a high school degree (for a review, see Fryers et al., 2003). Furthermore, a meta-analysis shows that one more year in education decreases the risk of having depressive symptoms by about 3 percent on average (Lorant et al., 2003). Thus, risks of mental illness are elevated in lower educated groups.

A detailed understanding of educational differences in mental health is of increasing scientific interest. It is deemed important to identify mechanisms that bring about effects on mental health and to quantify their relevance to develop and introduce tailored measures for mitigating health disparities. As the research literature shows, multiple mechanisms, such as labor-market related aspects (e.g. economic resources), psychological factors (e.g. self-efficacy), and factors related to social integration (e.g. number of confidants and social support), contribute different shares to the explanation of status-related differences in mental health. Moreover, aspects of social integration seem to contribute less compared to other mechanisms (e.g., Dalgard, 2008). However, studies that emphasize the relative importance of mechanisms in relation to others or the total effect of the analyzed dimension of status are scarce.

This study addresses the role of social integration into strong and weak ties, which provides opportunities for health-promoting psychosocial strategies to reduce educational inequalities in mental health (Berkman et al., 2000; Thoits, 2011). The main argument is that education determines different dimensions of social integration (i.e., the number of weak and strong ties), which in turn are positively related to mental health outcomes via psychosocial mechanisms (e.g., Murrell and Meeks, 2002; Vonneilich et al., 2012). In this regard, particular focus is also placed on the differences between weak and strong ties, as they may differ in mediating the influence of education, as suggested by Johnson et al.'s (2017) study.

To the best of our knowledge, there are only three studies that investigate the mediation effect of social integration in the relationship between education and mental health, and these studies 
show conflicting results. Based on a sample of adults from Kentucky (U.S.), Murrell and Meeks (2002) investigate how social support, measured by a scale considering functional or perceived support from weak and strong ties, mediates the effect of years of education on fatigue. They show that social support explains a small part of the education effect on mental health. The two other studies are concerned with the mediation effect in the link between education and depression. Ettner and Grzywacz (2003), using a sample of adults from California (U.S.), show that social integration, measured by the marital status and the number of children and friends, does not mediate the education effect. In contrast, Lee (2011) indicates that social integration, measured by marital status, the number of children, having at least one living siblings, and having at least one close friends, participation in the labor market and voluntary associations, explains some part of the relationship between different levels of education and depression in a sample with South Korean adults. While previous studies by Murrell and Meeks (2002), Ettner and Grzywacz (2003), and Lee (2011) provide valuable insights into the mediating effect via social integration, the results are far from conclusive.

In this study, we address several limitations of the previous research. First, since all three studies mentioned above refer to either depression or fatigue, the relevance of mediation for other dimensions of mental health (such as anxiety or a person's general mental health status) is still unclear. Therefore, we contribute to the existing research by focusing on individuals' selfassessments of their overall mental health status. Second, previous analyses have not yet addressed the question of whether strong and weak ties (Granovetter, 1973; Thoits, 2011) are equally important in mediating the effect of education on mental health. While Murrell and Meeks (2002) only focus on social support, which is determined by the level of social integration, Lee (2011) and Ettner and Grzywacz (2003) investigate the mediation effects considering only combined measures of social integration. Therefore, we go one step further by examining the role of social ties varying by their strength. Third, our analysis overcomes methodological limitations of previous studies. Lee (2011) possibly has overestimated the mediation effect as she included whether an individual has a job or not in the summary index, which may reflect mechanisms that are different from social integration, such as the lack of time structure due to unemployment (Jahoda, 1982). Therefore, we carefully selected measures, which do not capture concepts apart from social integration and are well-established in the social science literature. Moreover, Ettner and Grzywacz (2003) used relative risk ratios to compare changes in effect size and significance of coefficients for their test of mediation 
effects, which may lead to misleading conclusions (Breen et al., 2018). We avoid this problem by using linear probability models.

Addressing several limitations and open questions arising from previous studies, we analyze the extent to which social integration into strong and weak ties mediates the effect of education on mental health. Our analysis is based on twelve waves of German panel data. Furthermore, we conduct longitudinal mediation analysis to improve our understanding of the relevance of different social integration dimensions in this relationship. However, before that we must provide theoretical background in the following section.

\section{Theoretical considerations and hypotheses}

Education, which in the following refers to an individual's level of general and vocational education, is assumed to be a very important determinant for mental health. Different theoretical approaches exist which explain the relationship between education and mental health, these are based on economic, sociological, and psychological theories. They follow the argument that higher education leads to higher levels of various resources and, therefore, positively influences mental health (Bartley, 2017; Grossman, 2006). ${ }^{1}$ For example, education is related to elevated labor market-related outcomes, as well as increased social and psychological resources, which are all beneficial for mental health (Grossman, 2006; Lin, 2002; Ryan and Deci, 2000). In the following, we theorize how social integration acts as a mediator in this relationship. We begin by a short definition of social integration, continue with presenting arguments on how education affects social integration and then address the question of how social integration affects mental health.

Social integration is a multi-dimensional concept located at the macro, mezzo and micro level (Berkman et al., 2000). In this study, our focus lies on social integration at the mezzo level in terms of network size and tie strength. Both aspects of social embeddedness determine access to health-promoting psychosocial factors at the micro level. These are person-to-person contact, social support, social influence, social engagement, and access to material resources and goods. Regarding the tie strength of social ties, we differentiate between weak and strong ties (Granovetter, 1973; Thoits, 2011). Strong ties refer to relationships with members of small, intimate, and informal groups (e.g., families and peer groups), while weak ties are contacts with

\footnotetext{
${ }^{1}$ However, other theories that suggest an impact of mental health on education, but they are not the focus of this study. These selection processes seem to be more relevant at younger ages and should be less pronounced in middle and later adulthood (Ben-Shlomo \& Kuh 2002). Nevertheless, we come back to this in the discussion section.
} 
people from larger, more institutionalized, and more formal networks (e.g., colleagues from work, acquaintances in voluntary associations).

Theoretical considerations suggest that education positively affects two dimensions of social integration, namely the embeddedness in weak and strong ties (Erickson, 2004; Gesthuizen et al., 2008). Firstly, one reason is that individuals with different levels of education tend to differ in their opportunities to encounter others. The probability of meeting various other people and establishing social contacts correlates with the number of participating in different social settings (Erickson, 2004). Higher educated individuals are more likely to be involved in different educational (e.g., Jusri and Kleinert, 2018) and more formal social contexts (e.g., Erickson, 2004; Gesthuizen et al., 2008; Klein, 2015), as they are more likely to have attended different types of school, have completed vocational training or a university degree, and to participate in the labor market compared to individuals with lower education levels. More frequent changes between different social contexts are likely to increase an individual's pool of potential cohabitants, friends and acquaintances, increasing the number of weak and strong ties (Thomas, 2019).

Secondly, education increases the chances to gain social attractiveness. A higher level of education increases the chances to get a position of high social status and access to associated resources (Bourdieu, 1983; Bourdieu and Passeron, 1970; Erickson, 2004). This increases the attractiveness to others with similar or lower levels of education, possibly resulting in the formation of new network ties (e.g., meeting potential partners, making new friends) (Erickson, 2004; Lin, 2000). Thus, we assume that individuals with higher levels of education are more likely to increase their number of weak and strong ties due to their higher levels of social attractiveness.

Thirdly, we assume that education affects social integration through higher levels of social and verbal skills (Hsung and Lin, 2008), as these skills help to establish contact and to maintain social connections. Individuals with better social and verbal skills are more likely to initiate social contact effectively and appropriately and help to maintain social connections. For example, socially and verbally skilled individuals are able to adapt their behavior to a specific situation, to react accordingly, and to realize goals in social interactions (Merrell and Gimpel, 2014). Moreover, these skills are useful in managing social conflicts (Amato, 1996), such as disagreements, disputes and other problems in social relationships. This, in turn, increases the likelihood to uphold or increase the number of weak and strong ties. For instance, individuals 
are more easily able to make friends and acquaintances and avoid marital dissolution, family conflicts, or friendship breakdown. Consequently, we expect that social and verbal skills, which higher educated individuals acquired more often, increase the number of weak and strong ties.

Taken together, theoretical arguments imply that high educated individuals are better socially integrated into strong and weak ties than low educated individuals. ${ }^{2}$ This brings us to our first hypothesis:

\section{H1: The higher the individuals' educational levels the higher their level of social integration into strong and weak ties.}

One might argue that status inconsistencies possibly prevent educational degrees to pay off in terms of social integration. This is because individuals with high levels of education are, for instance, not necessarily employed, have high occupational status, or earn high incomes. This would limit their capabilities to increase social integration through participation in a variety social contexts and social attractiveness. Nevertheless, education should be positively linked to social embeddedness via the aforementioned mechanisms in the overall perspective although the educational degree does not improve social integration for a subgroup of higher educated.

In a next step, we focus on the relationship between social integration and mental health. Social ties are positively linked to mental health because social engagement likely increases the feeling of being loved and cared for and the feeling of security in uncertain situations. Moreover, it reinforces individuals' sense of identity and recognition. In addition, social ties may provide emotional support and protection from negative emotional consequences of stressors, thus deescalating the emotional strain of daily challenges (Berkman et al., 2000; Thoits, 2011). In case of critical life events, they might reduce an individual's symptoms of anxiety, depression, and psychological distress, for example, by the provision of material support (e.g. compensation of income loss due to unemployment). Finally, social ties should lead to better mental health by motivating individuals to take better care of themselves. For example, they might encourage,

\footnotetext{
${ }^{2}$ Most arguments imply that higher education increases the number of strong and weak ties. However, it also might be that education is not positively associated with both types of social ties, as higher and lower educated possibly follow different strategies (Gesthuizen et al., 2008). Higher educated might utilize their resources to invest in particular in social contacts that perpetuate their social status, such as weak ties in formal organizations, whereas lower educated might compensate their lack of resources by investing in particular in strong ties. This would suggest a negative link between education and strong ties. Against the background of our findings, we will come back to this in the last section (see section 5 Discussion and conclusion).
} 
persuade, remind, or pressure ego to adopt health-promoting practices (Thoits, 2011; Berkman et al., 2000; Umberson and Montez, 2010).

Social integration into social ties is also more likely to support mental health by providing information and promoting ego's social influence. First, social ties tend to provide better access to information about previously unknown options, chances, and assistance from helpful others, which would be otherwise not available (Thoits, 2011). For instance, they could be a valuable source of information about health-promoting practices or provide advice on solutions to previously unknown challenges. Second, social ties might be useful to exert social influence on important agents so that power and influence on decision-making processes (e.g., hiring processes) increases (Lin, 2002). This possibly prevents individuals from becoming or remaining unemployed, and likely increases their access to more positive working conditions, higher standard of living, or qualitative medical health care. These are factors all well-argued to affect better mental health (Cohen et al., 2000; Thoits, 2011).

Based on the aforementioned arguments, differences in social integration might explain some part of the relationship between education and mental health. While higher educated individuals are likely to have a higher level of social integration and mentally benefit from social engagement, social support, social influence, and access to resources and material goods; lower educated individuals lack these health-promoting psychosocial resources. This leads us to our second hypothesis: ${ }^{3}$

H2: The positive effect of education on mental health is partly mediated by individuals' levels of social integration into strong and weak ties.

\section{Data and methods}

\subsection{Data}

We tested these hypotheses with data from the Panel Study Labour Market and Social Security (PASS) of the Institute for Employment Research (IAB) in Germany (Bähr et al. 2019). The

\footnotetext{
${ }^{3}$ The focus of this study is on the pathway linking education and mental health via social integration. At the same time, education could also play an important role in the effect of social integration on mental health. According to the hypothesis of status-specific vulnerability (for an overview, see Vonneilich, 2022), lacking weak and strong ties have a greater impact on mental health for low status groups (low educated), as the social resources embedded in the network structures are unequally distributed across groups. We tested interactions of our social integration measures with years of education within our mediation analysis (see section 3.3 on the empirical strategy). Except for a very small interaction effect regarding active membership in a voluntary association based on a randomeffects model, however, we find no evidence for the hypothesis of status-specific vulnerability based on randomeffects and fixed-effects models (results available upon request).
} 
PASS data allows detailed analyses of inequalities in education, health, and social integration and includes a sufficient number of vulnerable people. The PASS contains two subsamples. The first subsample was drawn from individuals in households receiving welfare benefits (socalled Unemployment Benefit II), whereas the second subsample was drawn from the general population in Germany. With its focus not only on the general population but also on the special subgroup of recipients of unemployment benefits, the PASS includes a satisfactory number of individuals with low levels of education. In total, the PASS contains information on 46,000 individuals.

In our analysis, we used the waves one to twelve (2006/2007 to 2018) of both subsamples. In our analysis sample, first, we only considered individuals aged 30 up to 60 to ensure that most of the respondents had completed education and to avoid the mortality-based selection process in higher age groups. Second, we only included individuals in our analysis who were observed at least twice during the observation period and dropped all cases with missing values in the dependent, independent, or control variables. This result in a sample of 77,294 observations from 15,863 individuals (observed at 4.9 times on average), with about 9,971 individuals included in the sample of recipients of welfare benefits (subsample 1) and about 5,892 included in the general population sample (subsample 2). Detailed information on the sample characteristics can be found in Table A.1 and Table A.2 in Appendix A.

\subsection{Operationalization}

To measure education, we used the respondent's years of education derived from their highest educational qualification including general and vocational certificates. The measure is calculated by individuals' highest general educational level and years of different types of vocational education, such as training as a semi-skilled worker, apprenticeship, or vocational school attendance (Berg et al., 2020). The years of education ranges from 7 to 21 and is about 13 years for the general population sample and about 12 years for the sample of recipients of welfare benefits (see Table A.2 in Appendix A).

We measured mental health by using a well-established question addressing an individual's overall perception of his or her mental health, which not only indicates their overall mental health but also strongly correlates with morbidity rates and is a good predictor for different types of mental disorders, such as depression, panic disorders, schizophrenia (Ahmad et al., 2014; Mawani and Gilmour, 2010). Respondents were asked: "How strongly have you been affected by mental problems, such as fear, dejection or irritability in the past 4 weeks? Please 
tell me, whether you were affected 'not at all', 'a little bit', 'moderately', 'quite a bit' or 'extremely'?" (Müller et al. 2020). As with previous studies using self-rated health measurements, we dichotomized individuals' mental health status and created a variable indicating individuals with at least good mental health. We distinguished between respondents who stated that they were "not at all" or "a little bit" (=1) affected by mental health problems and those who reported being "moderately", "quite a bit" or "extremely" (=0) affected. Descriptive statistics are presented in Table A.2 of the Appendix A.

We decided to use this subjective mental health measure to take full advantage of our longitudinal data. Correlations between the SF-12 mental component summary scale, a generic and quasi-objective mental health measure (Ziebarth, 2010) that has been shown to be adequately valid and reliable in general populations (Cheak-Zamora et al., 2009), and our subjective mental health measure are about 0.7 at each time point both measures are available in the PASS (i.e., waves three, six, nine, and twelve). This suggests that our measure is highly related to the SF-12 mental component summary scale. The study of Ziebarth (2010) who assess the relationship between the SF-12 scale and subjective health measures comes to similar conclusions.

The social integration measures we use in our analysis cover different aspects of this theoretical concept on the mezzo level (Berkman et al., 2000). Firstly, we relied on a social integration index developed by Berkman (1979). This index represents one's overall level of social integration into strong and weak ties considering the relative importance of different types of social ties (Berkman 1979). ${ }^{4}$ The well-established index covers the respondent's partner status, the number of close friends and relatives outside the household and active participation in voluntary associations. Following, for instance, Berkman et al. (2004), Cannuscio et al. (2004), Eng et al (2002), and Vonneilich et al. (2012), we score individuals by characteristics of their networks in each of these dimensions (for detailed information see Table A.3 in Appendix A). The index ranges from 0 to 6 , while " 0 " indicates social isolation and " 6 " reflects a very high level of social integration (see Table A.4 in Appendix A) and the index sufficiently differentiates between individuals with a strikingly low or high number of close friends and relatives outside the household (see Figure A.1 in Appendix A).

\footnotetext{
${ }^{4}$ For detailed information about the construction and quality of the index see Berkman(1979),
} 
Secondly, to measure strong ties, we used a dummy variable that indicates whether the respondent is married or cohabited as well as the logarithm of the number of close friends and relatives outside the household (for descriptive statistics see Table A.2 in Appendix A). We logarithmized the number of close friends and relatives outside the household because the relative importance of one additional strong tie is assumed to decrease with the number of strong ties. We added the value 1 before we conducted the logarithmic transformation to keep the individuals without friends in our sample.

Thirdly, to capture weak ties, we rely on "active membership in a voluntary association". We built a variable indicating whether someone actively participates in at least one of the following voluntary associations: a labor union, a political party, a church congregation, a sports, music, or cultural club, or another association (for descriptive statistics see Table A.2 in Appendix A). According to Granovetter (1973: p. 1375), formal organizations as well as work setting are "two common sources of weak ties". Using memberships in voluntary associations as a measure of weak ties is also a common operationalization of this concept (e.g., Krug and Prechsl, 2022; Ruiter and Graaf, 2009; Uhlendorff, 2004). However, memberships in voluntary associations only provides a rough measure of weak ties, as this indicator neglects work environments as a source of weak ties and to a small extent captures strong tie relationships with other organization members. Regarding the latter, partial correlations of our social integration measures imply that active memberships in voluntary organizations only to a small extent comprises strong ties (see Table A.5 in the Appendix).

\subsection{Empirical strategy}

In the first part of our main analysis, we estimate random-effects models (RE). To estimate models including binary mental health as dependent variable, we used linear probability models with RE, which provide an appropriate alternative to logistic regression models (Breen et al., 2018). Our baseline model is as follows:

$$
\begin{aligned}
& \text { mhealth }_{i t}= \text { edu }_{i t} \beta_{1}+\text { gender }_{i} \beta_{2}+\text { migration background } \\
& \beta_{3}+\text { SES }_{i} \beta_{4} \\
&+ \text { sample }_{i} \beta_{5}+\text { children }_{i t} \beta_{6}+\text { state of residence } \\
& \beta_{7} \\
&+ \text { agegroup }_{i t} \beta_{8}+\text { wave }_{i t} \beta_{9}+c_{i}+u_{i t}
\end{aligned}
$$

mhealth $_{i t}$ is the dichotomous outcome variable and $e d u_{i t}$ is the focal independent variable of each individual $i$ at time point $t . \beta_{1}$ is the coefficient to be estimated that reflects the total effect of education. $u_{i t}$ is the idiosyncratic error term varying over time and between individuals. $c_{i}$ 
captures the time-constant individual-specific error-component. The RE estimator is based on the strict exogeneity assumption, implying both error components, $u_{i t}$ and $c_{i}$, to be uncorrelated with education (our focal independent variable) (Brüderl and Ludwig, 2015). This assumption is often violated, and one could argue that fixed-effects (FE) panel regressions provide a better alternative, as the FE approach eliminates bias due to unobserved time-constant characteristics. However, the FE approach is not appropriate in our case, as the variation in education is too small and the estimated effect of education would only be based on a selective group of adults with changes in education. In such a case, RE models provide a more appropriate solution.

To avoid bias of the effects of our independent key variables, we included time-constant and time-varying control variables to the RE models. The time-constant controls are gender, migration background, socio-economic background (SES) and sample affiliation (PASS welfare benefit recipients sample $=1$, general population sample $=0$ ); and the time-varying controls are the number of children, the current state of residence (West Germany $=1$, East Germany $=0$ ), age groups, and survey waves. Detailed information on the distributions of our controls is shown in Table A.1 in Appendix A. We carefully selected our controls to avoid overcontrol bias (Elwert and Winship, 2014), that is, we did not control for variables lying on the causal path between education and mental health (e.g., employment status or household income).

To test whether social integration mediates the relationship between education and mental health, we conduct a mediation analysis (Baron and Kenny, 1986; VanderWeele, 2015). We followed a three-step procedure to carve out mediation effects via social integration (for an overview see Figure 1) and repeated these steps for each social integration measure.

Figure 1: Coefficient estimated in the mediation analysis (stylized DAG)

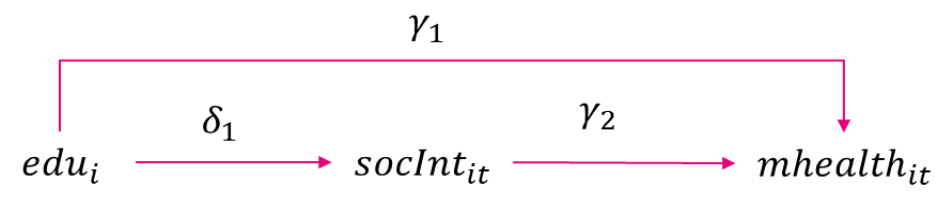

Source: Own illustration.

First, we analyze the effect $\left(\delta_{1}\right)$ of education on the mediator. Specifically, we estimate the following regression model with social integration $\left(\operatorname{socInt}_{i t}\right)$ as dependent variable: 


$$
\begin{gathered}
\text { socInt }_{i t}=\text { ed }_{i t} \delta_{1}+\text { gender }_{i} \delta_{2}+\text { migration background }_{i} \delta_{3}+S_{E S} S_{i} \delta_{4} \\
+\operatorname{sample}_{i} \delta_{5}+\text { children }_{i t} \delta_{6}+\text { state of residence }_{i t} \delta_{7} \\
+\operatorname{agegroup}_{i t} \delta_{8}+\text { wave }_{i t} \delta_{9}+v_{i}+w_{i t}
\end{gathered}
$$

Second, we analyze the effect of the mediator and the effect of education net of the mediator on mental health. Therefore, we augmented equation (1) by the mediator $\left(\operatorname{socInt}_{i t}\right)$, resulting in the following:

$$
\begin{aligned}
\text { mhealth }_{i t}= & \text { edu }_{i t} \gamma_{1}+\operatorname{socInt}_{i t} \gamma_{2}+\text { gender }_{i} \gamma_{3}+\text { migration background }_{i} \gamma_{4} \\
& + \text { SES }_{i} \gamma_{5}+\text { sample }_{i} \gamma_{6}+\text { children }_{i t} \gamma_{7}+\text { state of residence }_{i t} \gamma_{8} \\
& + \text { agegroup }_{i t} \gamma_{9}+\text { wave }_{i t} \gamma_{10}+\mu_{i}+\sigma_{i t}
\end{aligned}
$$

Equation (3) shows the effect $\left(\gamma_{2}\right)$ of social integration on mental health as well as the direct effect $\left(\gamma_{1}\right)$ of education on mental health, i.e., the education effect net of the mediator $\left(\operatorname{socInt}_{i t}\right){ }^{5}$ Calculating the difference between the total and the direct effect $\left(\beta_{1}-\gamma_{1}\right)$ renders the indirect effect of education on mental health that is mediated via the analyzed dimension of social integration (VanderWeele, 2015). We used Sobel tests (Sobel, 1982) and the bootstrapping method as suggested by Preacher and Hayes (2008) for significance tests of the indirect effects. We conducted a clustered bootstrapping procedure with 2000 iterations, which according to simulation studies leads to a sufficiently precise result (Gould \& Pitblado, n.d.).

The RE models we use in the mediation analysis might suffer from bias due to unobserved timeconstant characteristics. For the part of our mediation model in which we analyze the relationship between social integration and mental health (see Equation (3)), we can control for this source of bias by using FE models (for detailed information see Brüderl and Ludwig, 2015). The estimated effects of social integration based on FE models helps us to get closer to a causal interpretation, even if the effect only makes up a part of our mediation model. ${ }^{6}$ For instance, if

\footnotetext{
${ }^{5}$ As suggested by VanderWeele (2015), we tested for possible heterogeneity in mediation effects based on the focal independent variable (education). We followed this recommendation and tested whether our results vary by adding an interaction term between education and the mediator to the model. Except for memberships in voluntary associations, the interaction effects are very small and insignificant. Only the interaction effect of memberships in voluntary associations with education is very small, but barely significant at the 5-percent level. Overall, the interaction effects do not change the interpretation of our findings, so we decided to run the analyses without the interaction term (results available upon request).

${ }^{6}$ Although each FE model produces a coefficient representing the education effect on mental health, this should be interpreted with caution. The estimation of these coefficients is based on a selective group of adults with changes in education.
} 
social integration affects mental health based on the FE estimates, this would support a given mediation effect in the first part of the analysis, which is based on RE models.

\section{Results}

\subsection{Main results}

Our RE estimates are presented in Table 1 to Table 3. In a first step, we estimated the total effect $\left(\beta_{1}\right)$ of education on mental health (see Equation (1) in Section 3.3). Table 1 shows a positive association between education and mental health. One additional year of education is associated with an increase in the probability of reporting at least good mental health by 0.7 percentage points on average. This means, for example, that individuals with a general high school diploma and a university or master's degree, who have completed 18 years of education, are 7 percentage points more likely to report good mental health than individuals with a secondary school diploma without vocational training who have completed 8 years of education.

Table 1: The total effect of education on mental health $\left(\beta_{1}\right)$

\begin{tabular}{cc}
\hline & $\begin{array}{c}\text { At least good } \\
\text { mental health }\end{array}$ \\
\hline Years of education & $\begin{array}{c}0.0070^{* * *} \\
(0.0010)\end{array}$ \\
\hline
\end{tabular}

Source: PASS, Welle 12 v1 (DOI: 10.5164/IAB.PASS-SUF0618.de.en.v1), own calculation; N=15,863.

Note: Clustered standard errors in parentheses; ${ }^{*} p<0.05,{ }^{* *} p<0.01,{ }^{* * *} p<0.001$, model includes control variables, full regression models are presented in Tables A.6 to A.9 in Appendix A.

In the next step, we investigated the relationship between education and mental health via social integration. The results for the first part of the mediation chain, the effect of education $\left(\delta_{1}\right)$ on social integration (see Equation (2) in Section 3.3), are presented in Table 2. In line with our theoretical considerations, years of education are positively associated with social integration. One additional year of education increases the overall social integration by about 0.05 points on the 6-point scale, the probability of being married or cohabited by about 0.5 percentage points, and the number of close friends and relatives outside the household by about $1.6 \%$. In addition, the probability of active membership in a voluntary association increases by 2.5 percentage points with each year of additional education. All of this indicates that an individual's level of education is positively associated with their overall level of social integration, strong ties and weak ties, thus supporting our first hypothesis. 
Table 2: The effect of education on the mediators $\left(\delta_{1}\right)$

\begin{tabular}{lcccc}
\hline & $\begin{array}{c}\text { Overall level of } \\
\text { social integration }\end{array}$ & $\begin{array}{c}\text { Married or } \\
\text { cohabited }\end{array}$ & $\begin{array}{c}\text { Number of close } \\
\text { friends and } \\
\text { relatives outside } \\
\text { the household }(\mathrm{ln})\end{array}$ & $\begin{array}{c}\text { Active membership } \\
\text { in a voluntary } \\
\text { association }\end{array}$ \\
\hline Years of education & $\begin{array}{c}0.0469^{* * *} \\
(0.003)\end{array}$ & $\begin{array}{c}0.0049^{* * *} \\
(0.001)\end{array}$ & $\begin{array}{c}0.0157^{* * *} \\
(0.002)\end{array}$ & $\begin{array}{c}0.0247^{* * *} \\
(0.001)\end{array}$ \\
\hline
\end{tabular}

Source: PASS, Welle 12 v1 (DOI: 10.5164/IAB.PASS-SUF0618.de.en.v1), own calculation; N=15,863.

Note: Clustered standard errors in parentheses; ${ }^{*} p<0.05,{ }^{* * *} p<0.01,{ }^{* * *} p<0.001$, models include control variables, full regression models are presented in tables A.6 to A.9 in Appendix A.

Table 3 presents the results of the second part of the mediation model, which is the effect $\left(\gamma_{2}\right)$ of social integration on mental health (see Equation (3) in Section 3.3). As theoretically expected, we observe positive associations, which are in line with our theoretical considerations. Onepoint increase in overall social integration increases the probability of reporting at least good mental health by 2.1 percentage points on average. For the strong ties indicators we find the following: being married or cohabited increases the probability of reporting at least good mental health by about 5.3 percentage points and a 10 percent increase in friends increases this probability by approximately 0.4 percentage points. Finally, an active membership in a voluntary association (i.e. weak ties) increases the probability of at least good mental health by 2 percentage points on average.

Table 3: The Effect of social integration on mental health conditioned on education $\left(\gamma_{2}\right)$

\begin{tabular}{lc}
\hline & $\begin{array}{c}\text { At least good } \\
\text { mental health }\end{array}$ \\
\hline Overall level of social integration & $\begin{array}{c}0.0206^{* * * *} \\
(0.002)\end{array}$ \\
\hline Married or cohabited & $\begin{array}{c}0.0526^{* * *} \\
(0.005)\end{array}$ \\
\hline Number of close friends and relatives outside & $\begin{array}{c}0.0381^{* * *} \\
(0.003)\end{array}$ \\
\hline the household (ln) & $\begin{array}{c}0.0194^{* * *} \\
\text { Active membership in a voluntary association }\end{array}$ \\
\hline
\end{tabular}

Source: PASS, Welle 12 v1 (DOI: 10.5164/IAB.PASS-SUF0618.de.en.v1), own calculation; N=15,863.

Note: Clustered standard errors in parentheses; ${ }^{*} p<0.05,{ }^{* *} p<0.01,{ }^{* * *} p<0.001$, models include control variables, full regression models are presented in tables A.6 to A.9 in Appendix A.

Table 4 presents the decomposition of the total effect of education on mental health $\left(\beta_{1}\right)$ into the direct effect $\left(\gamma_{1}\right)$ of education and the indirect effect $\left(\beta_{1}-\gamma_{1}\right)$. We observe very small changes in the effect of education on mental health, when we control for different dimensions of social integration, and the indirect effects of education on mental health via social integration are in the range of 0.03 to 0.10 percentage points. The p-values of the indirect effects are based on Sobel (1982) and bootstrapped standard errors, but, as Table 4 shows, led to similar 
conclusions regarding statistical significance. Both indicate that all indirect effects are statistically significant different from zero.

Although the indirect effects are very small, they have to be regarded in the context of the small size of the total effect of education on mental health. Some of the mediators explain a substantial part of the total effect of education (see Table 4, column 4). The overall level of social integration contributes about $14 \%$ to the total effect of years of education, whereas the number of close friends and relatives outside the household contributes about $9 \%$, being married or cohabited contributes about $4 \%$, and an active membership in a voluntary association contributes about $7 \%$. Taken together, these results strongly support our second hypothesis.

Table 4: Decomposition of the effect of education on mental health

\begin{tabular}{|c|c|c|c|c|c|c|}
\hline Mediator & $\begin{array}{c}\text { Total effect } \\
\text { of education } \\
\text { on mental } \\
\text { health } \\
\beta_{1}\end{array}$ & $\begin{array}{c}\text { Effect of } \\
\text { education } \\
\text { on mental } \\
\text { health net of } \\
\text { the mediator } \\
\gamma_{1}\end{array}$ & $\beta_{1}-\gamma_{1}$ & $\begin{array}{l}\text { p-Value } \\
\text { (Sobel) }\end{array}$ & $\begin{array}{c}\text { p-Value } \\
\text { (boot) }\end{array}$ & $\begin{array}{c}\begin{array}{c}\text { Percent of } \\
\text { total effect }\end{array} \\
\frac{\left(\beta_{1}-\gamma_{1}\right)}{\beta_{1}} \times 100\end{array}$ \\
\hline $\begin{array}{l}\text { Overall level of social } \\
\text { integration }\end{array}$ & $\begin{array}{l}0.0070 * * * \\
(0.001)\end{array}$ & $\begin{array}{l}0.0060 * * * \\
(0.001)\end{array}$ & $\begin{array}{c}0.0010 * * * \\
(0.0001)\end{array}$ & 0.000 & 0.000 & $14.28 \%$ \\
\hline Married or cohabited & $\begin{array}{c}0.0070^{* * * *} \\
(0.001)\end{array}$ & $\begin{array}{c}0.0067 * * * \\
(0.001)\end{array}$ & $\begin{array}{c}0.0003^{* *} \\
(0.0002)\end{array}$ & 0.001 & 0.000 & $4.29 \%$ \\
\hline $\begin{array}{l}\text { Number of close } \\
\text { relatives and friends } \\
\text { outside the household } \\
\text { (ln) }\end{array}$ & $\begin{array}{c}0.0070 * * * \\
(0.001)\end{array}$ & $\begin{array}{c}0.0064 * * * \\
(0.001)\end{array}$ & $\begin{array}{c}0.0006^{* * * *} \\
(0.0001)\end{array}$ & 0.000 & 0.000 & $8.57 \%$ \\
\hline $\begin{array}{l}\text { Active membership in a } \\
\text { voluntary association }\end{array}$ & $\begin{array}{c}0.0070^{* * * *} \\
(0.001)\end{array}$ & $\begin{array}{c}0.0065^{* * * *} \\
(0.001)\end{array}$ & $\begin{array}{c}0.0005 * * * \\
(0.0001)\end{array}$ & 0.000 & 0.000 & $7.14 \%$ \\
\hline
\end{tabular}

Source: PASS, Welle 12 v1 (DOI: 10.5164/IAB.PASS-SUF0618.de.en.v1), own calculation; N=15,863.

Note: Clustered standard errors in parentheses; ${ }^{*} p<0.05,{ }^{* *} p<0.01,{ }^{* * *} p<0.001$, models include control variables.

Our results based on RE regressions reveal small indirect effects via the investigated dimensions of social integration. However, in this part of the analysis we did not control for unobserved confounders. Therefore, for the second part of our mediation model, we tested whether the effects of social integration on mental health disappear when we us FE models, which control for time-constant unobserved characteristics. The results based on FE regressions (see Table 5) imply effects of overall social integration, the number of close friends and relatives, and active membership in a voluntary association on mental health, while being married or cohabited seem to be unrelated. Furthermore, compared to the results based on RE models, the FE regression results indicate smaller associations of social integration on the probability of reporting at least good mental health. For instance, an additional unit of overall social integration increases the probability of reporting at least good mental health by about 4.7 percentage points based on RE and by about 0.7 percentage points based on FE. Furthermore, 
the coefficient of the number of friends and relatives is almost halved. This might imply that our RE estimates on the relationship between social integration and mental health suffer from bias due to unobserved heterogeneity. At the same time, three out of four indicators of social integration show to be determinants of mental health. So we can uphold the proposition that social integration is a mediator in the relationship between education and mental health.

Table 5: Results of the fixed-effects regressions for the effect of social integration on mental health

\begin{tabular}{lcc}
\hline & \multicolumn{2}{c}{ At least good mental health } \\
& $\mathbf{R E}$ & $\mathbf{F E}$ \\
\hline \multirow{2}{*}{ Overall level of social integration } & $0.0469^{* * *}$ & $0.0068^{* *}$ \\
& $(0.003)$ & $(0.003)$ \\
\hline \multirow{2}{*}{ Married or cohabited } & $0.0486^{* * *}$ & 0.0033 \\
Number of close friends and relatives outside the & $(0.005)$ & $(0.009)$ \\
\hline household (ln) & $0.0381^{* * *}$ & $0.0204^{* * *}$ \\
Active membership in a voluntary association & $(0.003)$ & $(0.004)$ \\
\hline
\end{tabular}

Source: PASS, Welle 12 v1 (DOI: 10.5164/IAB.PASS-SUF0618.de.en.v1), own calculation; N=15,863.

Note: Clustered standard errors in parentheses; ${ }^{*} p<0.05,{ }^{* *} p<0.01,{ }^{* * *} p<0.001$, standard errors clustered by individual, models include control variables, full regression models are presented in Table A.10 in Appendix A.

\subsection{Sensitivity analysis}

The mediation analysis presented thus far suggest that different dimensions of social integration partly mediate the relationship between education and mental health. However, it remains unclear if similar conclusions hold for overall subjective health, which is related to mental health, as it reflects physical and mental components of health (e.g., Bailis et al., 2003). We therefore conducted a mediation analysis with general subjective health as dependent variable. In line with our main analysis, higher education increases the probability of reporting at least good health (see Table 6, column 1) and the indirect effects are of similar size (see Table 6, column 4). However, depending on the larger coefficient of education, social integration explains a much smaller part of the overall effect of education on health (between 1.3 and $4.5 \%$ ) (see Table 6, column 5). In addition, FE estimates only support a complete causal pathway from education via the number of friends and relatives outside the household on self-rated overall health, while the coefficients of the other social integration indicators are close to zero (see Table 7). We conclude that social integration seems to be a less important mediator when the analyzed health outcome covers both, the mental and the physical component of health. 
Table 6: Robustness check for individuals overall health status

\begin{tabular}{|c|c|c|c|c|c|c|c|}
\hline Mediator & $\begin{array}{c}\text { Total effect } \\
\text { of } \\
\text { education } \\
\text { on health } \\
\boldsymbol{\beta}_{1}\end{array}$ & $\begin{array}{c}\text { Effect of } \\
\text { social } \\
\text { integration } \\
\text { on health } \\
\text { conditioned } \\
\text { on education } \\
\boldsymbol{\beta}_{2} \\
\end{array}$ & $\begin{array}{c}\text { Effect of } \\
\text { education } \\
\text { on health } \\
\text { net of the } \\
\text { mediator } \\
\gamma_{2}\end{array}$ & $\beta_{1}-\gamma_{2}$ & $\begin{array}{c}\text { p- } \\
\text { Value } \\
\text { (Sobel) }\end{array}$ & $\begin{array}{c}\text { p-Value } \\
\text { (boot) }\end{array}$ & $\begin{array}{l}\begin{array}{c}\text { Percent of } \\
\text { total effect }\end{array} \\
\frac{\left(\beta_{1}-\gamma_{1}\right)}{\beta_{1}} \\
\times 100 \\
\end{array}$ \\
\hline $\begin{array}{l}\text { Overall level of social } \\
\text { integration }\end{array}$ & $\begin{array}{c}0.0154 * * * \\
(0.001)\end{array}$ & $\begin{array}{c}0.0121 * * * \\
(0.002)\end{array}$ & $\begin{array}{c}0.0147 * * * \\
(0.001)\end{array}$ & $\begin{array}{c}0.0007 * * * \\
(0.0001)\end{array}$ & 0.000 & 0.000 & $4.54 \%$ \\
\hline Married or cohabited & $\begin{array}{c}0.0154 * * * \\
(0.001) \\
\end{array}$ & $\begin{array}{c}0.0284 * * * \\
(0.006)\end{array}$ & $\begin{array}{c}0.0152 * * * \\
(0.001)\end{array}$ & $\begin{array}{l}0.0002 * * \\
(0.0000)\end{array}$ & 0.004 & 0.000 & $1.30 \%$ \\
\hline $\begin{array}{l}\text { Number of close } \\
\text { relatives and friends } \\
\text { outside the household } \\
\text { (ln) }\end{array}$ & $\begin{array}{l}0.0154 * * * \\
(0.001)\end{array}$ & $\begin{array}{l}0.0272 * * * \\
(0.003)\end{array}$ & $\begin{array}{l}0.0149 * * * \\
(0.001)\end{array}$ & $\begin{array}{c}0.0005^{* * * *} \\
(0.0001)\end{array}$ & 0.000 & 0.000 & $3.25 \%$ \\
\hline $\begin{array}{l}\text { Active membership in } \\
\text { a voluntary } \\
\text { association }\end{array}$ & $\begin{array}{c}0.0154 * * * \\
(0.001)\end{array}$ & $\begin{array}{l}0.0129 * * \\
(0.004)\end{array}$ & $\begin{array}{l}0.0150 * * * \\
(0.001)\end{array}$ & $\begin{array}{c}0.0004 * * \\
(0.001)\end{array}$ & 0.002 & 0.001 & $2.60 \%$ \\
\hline
\end{tabular}

Source: PASS, Welle 12 v1 (DOI: 10.5164/IAB.PASS-SUF0618.de.en.v1), own calculation; N=15,863.

Note: Clustered standard errors in parentheses; ${ }^{*} p<0.05,{ }^{* *} p<0.01,{ }^{* * *} p<0.001$, standard errors clustered by individual, models include control variables, full regression models are presented in tables A.11 to A.14 in Appendix A.

Table 7: Results of the fixed-effects regressions for the effect of social relationships on overall good health

\begin{tabular}{lc}
\hline & At least good overall health \\
\hline \multirow{2}{*}{ Overall level of social integration } & 0.001 \\
\multirow{2}{*}{ Married or cohabited } & $(0.003)$ \\
\hline Number of close friends and relatives outside the household & -0.012 \\
$($ ln) & $0.010)$ \\
\hline \multirow{2}{*}{ Active membership in a voluntary association } & $0.014^{* * *}$ \\
& $(0.004)$ \\
\hline
\end{tabular}

Source: PASS, Welle 12 v1 (DOI: 10.5164/IAB.PASS-SUF0618.de.en.v1), own calculation; N=15,863, separate estimations for each indicator of the number of social relationships.

Note: Clustered standard errors in parentheses; ${ }^{*} p<0.05,{ }^{* *} p<0.01,{ }^{* * *} p<0.001$, models include control variables, full regression models are presented in Table A.15 in Appendix A.

\section{Discussion and conclusion}

In this study, we investigated the relevance of social integration as mediator in the educationhealth relationship. With data from the Panel Study Labour Market and Social Security (PASS), first, we estimated the association between years of education and mental health based on RE models, which shows to be relatively small compared to the associations of other social status indicators (e.g., income) and mental health (e.g., Andersen et al., 2009). Second, we tested the hypothesis that education affects the number of social relationships (H1). The results suggest that education is positively associated with weak and strong ties, which is in line with previous studies (e.g. Gesthuizen et al. 2008). Third, we investigated whether these aspects of social integration mediate the relationship between education and mental health $(\mathrm{H} 2)$. To address this research question, we conducted a mediation analysis, which enables us to identify mechanisms 
in the relationship between education and mental health and to quantify their relevance. Our mediation analysis reveals that weak and strong ties partly explain the link between education and mental health. In particular, the number of close friends and relatives seems to be important as it explains about $9 \%$ of the total effect of education. This finding is supported by our analysis of the relationship between social integration and mental health based on FE models, which control for time-constant unobserved confounders. Our results are highly comparable with other studies examining the mediation effect of social factors (e.g. Ettner \& Grzywacz, 2003, Murrell \& Meeks 2002, Lee 2011). However, they point to much smaller mediation effects as shown by studies examining other mechanisms, such as psychosocial factors or individuals' labor market position (e.g. Dalgard 2008, Milner et al. 2018, Sperandei et al. 2021).

Our findings have several theoretical implications. First, our findings support the theoretical considerations regarding the association of education and social integration. Higher educated individuals are more likely to have a higher number of weak and strong ties, however, it remains unclear to what extent the participation in a variety of social settings, social attractiveness, and social and verbal skills can explain the differences in social integration between higher and lower educated individuals. In addition, our findings do not indicate that higher educated are prone to invest in weak ties because of their better resource endowments, while lower educated are prone to invest in strong ties, as suggested by Gesthuizen et al. (2008). Second, our findings support theories on the relationship between social integration and mental health. It is hypothesized that both weak and strong ties are dimensions of social integration that are important for sustaining mental health of individuals. However, we cannot say which of the mechanisms linking social integration to mental health we discussed in the theory section, such as social support and social influence, are relevant in this relationship. ${ }^{7}$ Third, findings from our mediation model imply that multiple aspects of social integration are at work in the relationship between education and mental health, which should be taken into account by theoretical considerations.

Our study also has some limitations that should be considered by future research. First, our indicators of weak and strong ties do not cover all sources of weak and strong ties, respectively. For instance, our measures do not cover children (strong ties) or weak ties that solely exist in the work context, which are independent of active membership in a voluntary association.

\footnotetext{
${ }^{7}$ This question should be addressed by future research. As a first step, we also tested the link between education, social support, and mental health in a further analysis. Results indicate that financial social support partly mediates the relationship between education and mental health (see Table B.1 to Table B.4 in Appendix B).
} 
Moreover, the scope of our analysis is limited to certain aspects of social integration, but the effect of education on mental health could also be explained by other network structures or characteristics, such as the reciprocity of ties or the network density (for an overview, see Berkman et al., 2000). This should be addressed in future research. Second, although we eliminated time-constant unobserved heterogeneity when estimating the effect of social integration on mental health based on FE models, we were not able to thoroughly estimate the effect of years of education with this method as the within-variation in our data is small and estimated effects would rely on a selective group of adults with changes in education. Thus, parts of our results might be subject to bias by unobserved heterogeneity. Third, it is important to note that our research question is concerned with the association between education and health after the respondents usually completed their educational degree. That is, we cannot rule out selection of healthier individuals in higher educational tracks (West, 1991), which already occurred before our observation period.

Despite these limitations, however, we contribute to the literature on the association between education and mental health via social integration. Firstly, our study provides a more finely graded understanding of this pathway, as our investigation takes different aspects of social integration into account, complementing the studies provided by Ettner and Grzywacz, 2003, Murrell and Meeks (2002), and Lee (2011). Secondly, we show that social integration is not only a channel through which levels of fatigue or depression are affected, as suggested by Murrell and Meeks (2002) and Lee (2011), but also the self-rated mental health. Thirdly, unlike previous studies, we account for time-constant unobserved heterogeneity in the analysis of the second part of the mediation chain and are able to show that our conclusions hardly change by this. Finally, we further contribute to the literature by replicating the analysis with the self-rated overall health as dependent variable, which is closely related to the dependent variable of our main analysis. In line with the previous research (e.g. Antonucci et al., 2003; Ettner and Grzywacz, 2003; Marmot et al., 1998; Vonneilich et al., 2012), we found small mediation effects in the education-health relationship, indicating higher relevance of other mechanisms. Furthermore, our results only support mediation via number of close friends and relatives.

The in-depth insights of this study raise discussions about the importance of social integration for the different dimensions of health. The empirical results of this study cast doubt on the proposition that mediation effects of social integration on mental and overall health are of equal relevance. That is, the number of strong and weak ties seems to be less relevant for educational differences in general health, suggesting that the physical health component of this 
measurement reduces the relative importance of social integration. In turn, this raises the question of the different channels linking education to physical and mental health. However, to the best of our knowledge, these differences have hardly been investigated so far. While some studies have examined the relevance of different mediators in the relationship between education and health for various health measures (e.g., Ettner and Grzywacz, 2003; Murrell and Meeks, 2002), they provide no information on the explanatory contribution of different mediators. This should be addressed by further research. 


\section{References}

Ahmad, F., Jhajj, A. K., Stewart, D. E., Burghardt, M., and Bierman, A. S. (2014). Single item measures of self-rated mental health: A scoping review. BMC Health Services Research, 14(389), 1-11. https://doi.org/10.1186/1472-6963-14-398.

Amato, P. R. (1996). Explaining the intergenerational transmission of divorce. Journal of Marriage and the Family, 58(3), 628-640. https://doi.org/10.2307/353723.

Andersen, I., Thielen, K., Nygaard, E., \& Diderichsen, F. (2009). Social inequality in the prevalence of depressive disorders. Journal of Epidemiology \& Community Health, 63(7), 575-581. http://dx.doi.org/10.1136/jech.2008.082719.

Antonucci, T. C., Ajrouch, K. J., and Janevic, M. R. (2003). The effect of social relations with children on the education-health link in men and women aged 40 and over. Social Science \& Medicine, 56(5), 949-960. https://doi.org/10.1016/S0277-9536(02)00099-0.

Bähr, S., Beste, J., Coban, M., Dummert, S., Friedrich, M., Fordermann, C., Gundert, S., Müller, B., Schwarz, S., Teichler, N., Trappmann, M., Unger, S., Wenzig, C., Berg, M., Cramer, R., Dickmann, C., Gilberg, R., Jesske, B., Kleudgen, M. (2019). "Panel Study Labour Market and Social Security (PASS) - Version 0618 v1". Research Data Centre of the Federal Employment Agency (BA) at the Institute for Employment Research (IAB). https://doi.org/10.5164/IAB.PASS-SUF0618.de.en.v1.

Bailis, D. S., Segall, A., and Chipperfield, J. G. (2003). Two views of self-rated general health status. Social Science \& Medicine, 56(2), 203-217. https://doi.org/10.1016/s02779536(02)00020-5.

Baron, R. M. and Kenny, D. A. (1986). The moderator - mediator variable distinction in social psychological research. Conceptual, strategic, and statistical considerations. Journal of Personality and Social Psychology, 51(6), 1173-1182. https://doi.org/10.1037/00223514.51.6.1173.

Barr, B., Kinderman, P., \& Whitehead, M. (2016). Trends in mental health inequalities in England during a period of recession, austerity and welfare reform 2004 to 2013: $\begin{array}{llllll}\text { Corrigendum. Social } & \text { Science } \quad \& \quad \text { Medicine, } & 160, & 129 .\end{array}$ https://doi.org/10.1016/j.socscimed.2016.05.020

Bartley, M. (2017). Health inequality. An introduction to concepts, theories and methods. Cambridge, UK, Malden, MA, USA: Polity. 
Ben-Shlomo, Y., \& Kuh, D. (2002). A life course approach to chronic disease epidemiology: conceptual models, empirical challenges and interdisciplinary perspectives. International Journal of Epidemiology, 31(2), 285-293. https://doi.org/10.1093/ije/31.2.285.

Berg, M., Cramer, R., Dickmann, C., Gilberg, R., Jesske, B., Kleudgen, M., Beste, J., Dummert, S., Frodermann, C., Schwarz, S., Trappmann, M., Bähr, S., Coban, M., Friedrich, M., Gundert, S., Müller, B., Teichler, N., Unger, S., and Wenzig, C. (2020). FDZDatenreport. Documentation on labour market data. Codebook and documentation of the Panel Study „Labour Market and Social Security“ (PASS) Datenreport Wave 12. Nuremberg.

Berkman, L.F. (1979). Social networks, host resistance, and mortality: A follow-up study of Alameda County residents. Doctoral dissertation. University of California, Berkeley.

Berkman, L. F., Glass, T., Brissette, I., and Seeman, T. E. (2000). From social integration to health. Durkheim in the new millennium. Social Science \& Medicine, 51(6), 843-857. https://doi.org/10.1016/s0277-9536(00)00065-4.

Berkman, L. F., Melchior, M., Chastang, J.-F., Niedhammer, I., Leclerc, A., and Goldberg, M. (2004). Social integration and mortality: A prospective study of French employees of Electricity of France-Gas of France: The GAZEL Cohort. American Journal of Epidemiology, 159(2), 167-174. https://doi.org/10.1016/S0277-9536(00)00065-4.

Bourdieu, P. (1983). Ökonomisches Kapital, kulturelles Kapital, soziales Kapital. In Kreckel, R. (Ed.). Soziale Ungleichheiten (pp. 183-198).

Bourdieu, P. and Passeron, J.-C. (1970). La reproduction. Paris, Minuit.

Breen, R., Karlson, K. B., and Holm, A. (2018). Interpreting and understanding logits, probits, and other nonlinear probability models. Annual Review of Sociology, 44(1), 39-54. https://doi.org/10.1146/annurev-soc-073117-041429.

Brüderl, J. and Ludwig, V. (2015). Fixed-effects panel regression. In Best, H. and Wolf, C. (Eds.). The Sage handbook of regression analysis and causal inference (pp. 327-357).

Cannuscio, C. C., Colditz, G., Rimm, E. B., Berkman, L. F., Jones, C. P., Kawachi, I. (2004). Employment status, social ties, and caregivers' mental health. Social Science \& Medicine, 58(7), 1247-1256. https://doi.org/10.1016/S0277-9536(03)00317-4. 
Cheak-Zamora, N. C., Wyrwich, K. W., \& McBride, T. D. (2009). Reliability and validity of the SF-12v2 in the medical expenditure panel survey. Quality of Life Research, 18(6), 727-735. https://doi.org/10.1007/s11136-009-9483-1.

Cohen, S., Gottlieb, B. H., and Underwood, L. G. (2000). Social relationships and health. In S. Cohen, L. G. Underwood, \& B. H. Gottlieb (Eds.), Social support measurement and intervention (pp. 3-26). https://doi.org/10.1093/med:psych/9780195126709.003.0001.

Dalgard, O. S. (2008). Social inequalities in mental health in Norway: possible explanatory factors. International journal for equity in health, 7(27). https://doi.org/10.1186/14759276-7-27.

Elwert, F. and Winship, C. (2014). Endogenous selection bias: The problem of conditioning on a collider variable. Annual Review of Sociology, 40, 31-53. https://doi.org/10.1146/annurev-soc-071913-043455.

Eng, P. M., Rimm, E. B., Fitzmaurice, G., \& Kawachi, I. (2002). Social ties and change in social ties in relation to subsequent total and cause-specific mortality and coronary heart disease incidence in men. American journal of epidemiology, 155(8), 700-709. https://doi.org/10.1093/aje/155.8.700

Erickson, B. H. (2004). The distribution of gendered social capital in Canada. In Flap, H. and Völker, B. (Eds.). Creation and returns of social capital (pp. 27-50).

Ettner, S. L. and Grzywacz, J. G. (2003). Socioeconomic status and health among Californians: An examination of multiple pathways. American Journal of Public Health, 93(3), 441444. https://doi.org/10.2105/ajph.93.3.441.

Fryers, T., Melzer, D., and Jenkins, R. (2003). Social inequalities and the common mental disorders: A systematic review of the evidence. Social Psychiatry and Psychiatric Epidemiology, 38(5), 229-237. https://doi.org/10.1007/s00127-003-0627-2.

Gesthuizen, M., van der Meer, T., and Scheepers, P. (2008). Education and dimensions of social capital. Do educational effects differ due to educational expansion and social security expenditure? European Sociological Review, 24(5), 617-632. https://doi.org/10.1093/esr/jen021.

Gould, W. \& Pitbaldo, J. (n.d.). Guidelines for bootstrap samples. Stata FAQs. URL: https://www.stata.com/support/faqs/statistics/bootstrapped-samples-guidelines/ (last access: September $12^{\text {th }}$ 2009) 
Granovetter, M. S. (1973). The strength of weak ties. American Journal of Sociology, 78(6), 1360-1380. http://www.jstor.org/stable/2776392.

Grossman, M. (2006). Education and nonmarket outcomes. In Hanushek, E. A. and Welch, F. (Eds.). Handbook of the Economics of Education. Volume 1 (pp. 578-633).

Halpern-Manners, A., Schnabel, L., Hernandez, E. M., Silberg, J. L., and Eaves, L. J. (2016). The relationship between education and mental health. New evidence from a discordant twin study. Social Forces, 95(1), 107-131. https://doi.org/10.1093/sf/sow035.

Hsung, R.-M. and Lin, Y.-J. (2008). Social capital of personnel managers: Causes and return of position-generated networks and participation in voluntary associations. In Lin, N. and Erickson, B. (Eds.). Social Capital: An International Research Program (pp. 234-254). https://doi.org/10.1093/acprof:oso/9780199234387.003.0107.

Jahoda, M. (1982). Employment and unemployment. Cambridge: Cambridge University Press. Jenkinson, C., Layte, R., Jenkinson, D., Lawrence, K., Petersen, S., Paice, C. \& Stradling, J. (1997): A shorter form health survey: can the SF-12 replicate results from the SF-36 in longitudinal studies? Journal of Public Health Medicine, 19(2), 179-186.

Johnson, C. M., Rostila, M., Svensson, A. C., \& Engström, K. (2017). The role of social capital in explaining mental health inequalities between immigrants and Swedish-born: a population-based cross-sectional study. BMC public health, 17(117). https://doi.org/10.1186/s12889-016-3955-3.

Jusri, R. and Kleinert, C. (2018). Haben höher Gebildete mehr Sozialkapital? Ungleichheit im Zugang zu sozialen Netzwerkressourcen. Sozialer Fortschritt, 67(4), 249-268. https://doi.org/10.3790/sfo.67.4.249.

Klein, M. (2015). The increasing unemployment gap between the low and high educated in West Germany. Structural or cyclical crowding-out? Social Science Research, 50, 110 125. https://doi.org/10.1016/j.ssresearch.2014.11.010.

Krug, G., \& Prechsl, S. (2022). Do changes in network structure explain why unemployment damages health? Evidence from German panel data. Social Science \& Medicine, 307, 115-161. https://doi.org/10.1016/j.socscimed.2022.115161.

Lee, J. (2011). Pathways from education to depression. Journal of Cross-Cultural Gerontology, 26(2), 121-135. https://doi.org/10.1007/s10823-011-9142-1. 
Lin, N. (2000). Inequality in social capital. Contemporary Sociology, 29(6), 785-795. https://doi.org/10.2307/2654086.

Lin, N. (2002). Social capital. A theory of social structure and action. Cambridge: Cambridge University Press.

Liu, N. H., Daumit, G. L., Dua, T., Aquila, R., Charlson, F., Cuijpers, P., Druss, B., Dudek, K., Freeman, M., Fujii, C., Gaebel, W., Hegerl, U., Levav, I., Munk Laursen, T., Ma, H., Maj, M., Elena Medina-Mora, M., Nordentoft, M., Prabhakaran, D., Pratt, K., Prince, M., Rangaswamy, T., Shiers, D., Susser, E., Thornicroft, G., Wahlbeck, K., Fekadu Wassie, A., Whiteford, H., and Saxena, S. (2017). Excess mortality in persons with severe mental disorders: A multilevel intervention framework and priorities for clinical practice, policy and research agendas. World Psychiatry: Official Journal of the World Psychiatric Association (WPA), 16(1), 30-40. https://doi.org/10.1002/wps.20384.

Lorant, V., Deliège, D., Eaton, W., Robert, A., Philippot, P., and Ansseau, M. (2003). Socioeconomic inequalities in depression: A meta-analysis. American Journal of Epidemiology, 157(2), 98-112. https://doi.org/10.1093/aje/kwf182.

Marmot, M. G., Fuhrer, R., Ettner, S. L., Marks, N. F., Bumpass, L. L., and Ryff, C. D. (1998). Contribution of psychosocial factors to socioeconomic differences in health. The Milbank Quarterly, 76(3), 403-448. https://doi.org/10.1111/1468-0009.00097.

Mawani, F. N. and Gilmour, H. (2010). Validation of self-rated mental health. Health Reports. A Canadian Peer-Reviewed Journal of Population Health and Health Services Research, $61-75$.

Merrell, K. W. and Gimpel, G. (2014). Social skills of children and adolescents. Conceptualization, assessment, treatment. Hoboken: Taylor and Francis.

Milner, A., Blakely, T., Disney, G., Kavanagh, A. M., LaMontagne, A. D., \& Aitken, Z. (2018). Do employment factors reduce the effect of low education on mental health? A causal mediation analysis using a national panel study. International journal of epidemiology, 47(5), 1423-1431.

Müller, B., Bähr, S., Gundert, S., Teichler, N., Unger, S., \& Wenzig, C. (2020). FDZMethodenreport. Methodological aspects of labour market data (07/2020). Institute for Employment Research, Nuremberg. 
Murrell, S. A. and Meeks, S. (2002). Psychological, economic, and social mediators of the education-health relationship in older adults. Journal of Aging and Health, 14(4), 527550. https://doi.org/10.1177/089826402237182.

OECD (2021). A new benchmark for mental health systems. OECD Policy Studies (OECD Publishing), Paris. https://doi.org/10.1787/4ed890f6-en.

Preacher, K. \& Hayes, A. (2008). Asymptotic and resampling strategies for assessing and comparing indirect effects in multiple mediator models. Behavior Research Methods, 40(3), 879-891. https://doi.org/10.3758/BRM.40.3.879.

Ruiter, S. and Graaf, N. D. de (2009). Socio-economic payoffs of voluntary association involvement. A Dutch life course study. European Sociological Review, 25(4), 425-442. https://doi.org/10.1093/esr/jen051.

Ryan, R. M. and Deci, E. L. (2000). Self-determination theory and the facilitation of intrinsic motivation, social development, and well-being. American Psychologist, 55(1), 68-78. https://doi.org/10.1037//0003-066X.55.1.68.

Sobel, M. E. (1982). Asymptotic confidence intervals for indirect effects in structural equation models. Sociological Methodology, 13, 290-312. https://doi.org/10.2307/270723.

Sperandei, S., Page, A., Spittal, M. J., \& Pirkis, J. (2021). Low education and mental health among older adults: the mediating role of employment and income. Social Psychiatry and Psychiatric Epidemiology, 1-9.

Thoits, P. A. (2011). Mechanisms linking social ties and support to physical and mental health. Journal of Health and Social Behavior, 52(2), 145-161. https://doi.org/10.1177/0022146510395592.

Thomas, R. (2019). Sources of friendship and structurally induced homophily across the Life $\begin{array}{llll}\text { course. } & \text { Sociological } & \text { 822-843) }\end{array}$ https://doi.org/10.1177/0731121419828399.

Uhlendorff, A. (2004). Der Einfluss von Persönlichkeitseigenschaften und sozialen Ressourcen auf die Arbeitslosigkeitsdauer. KZfSS Kölner Zeitschrift für Soziologie und Sozialpsychologie, 56(2), 279-303. https://doi.org/10.1007/s11577-004-0035-y.

Umberson, D. and Montez, J. K. (2010). Social relationships and health: A flashpoint for health policy. Journal of Health and Social Behavior, 51, S54-S66. https://doi.org/10.1177/0022146510383501. 
VanderWeele, T. (2015). Explanation in causal inference. Oxford: Oxford University Press.

Vonneilich, N., Jockel, K.-H., Erbel, R., Klein, J., Dragano, N., Siegrist, J., and von dem Knesebeck, O. (2012). The mediating effect of social relationships on the association between socioeconomic status and subjective health - results from the Heinz Nixdorf Recall cohort study. BMC Public Health, 12(285), 1-11. https://doi.org/10.1186/14712458-12-285.

Vonneilich, N. (2022). Social Status, Social Relations, and Health. In: Klärner, A., Gamper, M., Keim-Klärner, S., Moor, I., von der Lippe, H., Vonneilich, N. (eds) Social Networks and Health Inequalities. Springer, Cham. https://doi.org/10.1007/978-3-03097722-1_11

West, P. (1991). Rethinking the health selection explanation for health inequalities. Social Science \& Medicine, 32(4), 373-384. https://doi.org/10.1016/0277-9536(91)90338-D.

World Health Organization (2019). Mental health: Fact sheet. Retrieved from Regional Office for Europe website: https://www.euro.who.int/_data/assets/pdf_file/0004/404851/MNH_FactSheet_ENG.p df

Ziebarth, N. (2010). Measurement of health, health inequality, and reporting heterogeneity. Social Science \& Medicine, 71(1), 116-124. https://doi.org/10.1016/j.socscimed.2010.03.016. 


\section{Appendix A}

Table A.1: Descriptive statistics of the sample

\begin{tabular}{|c|c|c|c|c|c|c|c|c|c|}
\hline & & \multicolumn{4}{|c|}{$\begin{array}{c}\text { Subsample 1- } \\
\text { recipients of welfare benefits } \\
N=9,971\end{array}$} & \multicolumn{4}{|c|}{$\begin{array}{c}\text { Subsample 2- } \\
\text { general population sample } \\
N=5,892\end{array}$} \\
\hline & & mean & $s d$ & $\min$ & $\max$ & mean & $s d$ & $\min$ & $\operatorname{Max}$ \\
\hline Female & & 0.56 & & & & 0.56 & & & \\
\hline With migration background & & 0.27 & & & & 0.14 & & & \\
\hline \multicolumn{10}{|l|}{$\begin{array}{l}\text { Socio-economic background } \\
\text { (highest educational level of } \\
\text { parents) }\end{array}$} \\
\hline $\begin{array}{l}\text { max. lower secondary } \\
\text { school degree }\end{array}$ & & 0.54 & & & & 0.60 & & & \\
\hline $\begin{array}{l}\text { intermediate secondary } \\
\text { education }\end{array}$ & & 0.17 & & & & 0.18 & & & \\
\hline higher secondary education & & 0.16 & & & & 0.16 & & & \\
\hline $\begin{array}{l}\text { other school degree or } \\
\text { unknown }\end{array}$ & & 0.13 & & & & 0.05 & & & \\
\hline \multicolumn{10}{|l|}{ Age groups } \\
\hline \multirow[t]{3}{*}{30 to 39} & overall & 0.32 & 0.46 & & & 0.20 & 0.40 & & \\
\hline & between & & 0.45 & & & & 0.39 & & \\
\hline & within & & 0.18 & -0.60 & 1.24 & & 0.19 & -0.71 & 1.12 \\
\hline \multirow[t]{3}{*}{40 to 49} & overall & 0.32 & 0.47 & & & 0.37 & 0.48 & & \\
\hline & between & & 0.40 & & & & 0.40 & & \\
\hline & within & & 0.28 & -0.60 & 1.24 & & 0.31 & -0.55 & 1.28 \\
\hline \multirow[t]{3}{*}{50 to 60} & overall & 0.35 & 0.48 & & & 0.43 & 0.50 & & \\
\hline & between & & 0.44 & & & & 0.45 & & \\
\hline & within & & 0.21 & -0.56 & 1.28 & & 0.24 & -0.49 & 1.35 \\
\hline \multirow[t]{3}{*}{ West Germany } & overall & 0.66 & 0.47 & & & 0.80 & 0.40 & & \\
\hline & between & & 0.46 & & & & 0.40 & & \\
\hline & within & & 0.05 & -0.25 & 1.57 & & 0.04 & -0.09 & 1.71 \\
\hline \multirow[t]{3}{*}{ Number of children } & overall & 1.60 & 1.38 & & & 1.69 & 1.17 & & \\
\hline & between & & 1.37 & & & & 1.14 & & \\
\hline & within & & 0.37 & -3.73 & 5.60 & & 0.34 & -2.47 & 9.89 \\
\hline
\end{tabular}

Source: PASS, Welle 12 v1 (DOI: 10.5164/IAB.PASS-SUF0618.de.en.v1), own calculation. 
The Intervening Role of Social Integration in the Effect of Education on Subjective Mental Health

Table A.2: Descriptive statistics of the main variables

\begin{tabular}{|c|c|c|c|c|c|c|c|c|c|}
\hline & & \multicolumn{4}{|c|}{$\begin{array}{c}\text { Subsample } 1- \\
\text { recipients of welfare benefits } \\
N=9,971\end{array}$} & \multicolumn{4}{|c|}{$\begin{array}{c}\text { Subsample 2- } \\
\text { general population sample } \\
N=5,892\end{array}$} \\
\hline & & mean & $S d$ & $\min$ & $\max$ & mean & $s d$ & $\min$ & $\max$ \\
\hline \multirow[t]{3}{*}{ Years of education } & overall & 11.81 & 2.62 & 7 & 21 & 12.93 & 2.87 & 7 & 21 \\
\hline & between & & 2.71 & 7 & 21 & & 2.88 & 7 & 21 \\
\hline & within & & 0.22 & 7.36 & 15.97 & & 0.20 & 6.97 & 17.47 \\
\hline \multirow[t]{3}{*}{ At least good mental health } & overall & 0.60 & 0.49 & & & 0.70 & 0.46 & & \\
\hline & between & & 0.36 & & & & 0.33 & & \\
\hline & within & & 0.35 & -0.31 & 1.52 & & 0.34 & -0.21 & 1.62 \\
\hline \multirow[t]{3}{*}{ At least good overall health } & overall & 0.39 & 0.49 & & & 0.52 & 0.50 & & \\
\hline & between & & 0.37 & & & & 0.36 & & \\
\hline & within & & 0.34 & -0.52 & 1.31 & & 0.36 & -0.40 & 1.43 \\
\hline \multirow[t]{3}{*}{ Level of social integration } & overall & 2.58 & 1.25 & 1 & 6 & 3.61 & 1.20 & & \\
\hline & between & & 1.12 & 1 & 6 & & 1.08 & & \\
\hline & within & & 0.57 & -0.86 & 6.42 & & 0.56 & 0.39 & 6.69 \\
\hline \multicolumn{10}{|l|}{ Strong social relationships } \\
\hline \multirow[t]{3}{*}{ Married or cohabited } & overall & 0.52 & 0.50 & & & 0.83 & 0.40 & & \\
\hline & between & & 0.47 & & & & 0.36 & & \\
\hline & within & & 0.18 & -0.40 & 1.44 & & 0.13 & -0.09 & 1.74 \\
\hline \multirow{3}{*}{$\begin{array}{l}\text { Friends and relatives } \\
\text { outside the household }(\ln )\end{array}$} & overall & 1.90 & 0.63 & 0.69 & 4.61 & 1.20 & 0.62 & 0.69 & 4.61 \\
\hline & between & & 0.52 & 0.69 & 4.60 & & 0.52 & 0.69 & 4.36 \\
\hline & within & & 0.40 & -0.47 & 4.65 & & 0.38 & -0.12 & 4.31 \\
\hline \multicolumn{10}{|l|}{ Weak social relationships } \\
\hline \multirow{3}{*}{$\begin{array}{l}\text { Active membership in a } \\
\text { voluntary association }\end{array}$} & overall & 0.34 & 0.47 & & & 0.59 & 0.49 & & \\
\hline & between & & 0.38 & & & & 0.41 & & \\
\hline & within & & 0.29 & -0.58 & 1.26 & & 0.29 & -0.33 & 1.51 \\
\hline
\end{tabular}

Source: PASS, Welle 12 v1 (DOI: 10.5164/IAB.PASS-SUF0618.de.en.v1), own calculation. 
Table A.3: Dimensions of social integration and definition of score levels

\begin{tabular}{llc}
\hline & & score points \\
\hline Married or cohabited & No & 0 \\
& Yes & 2 \\
\hline Number of friends and relatives & 0 to 2 & 0 \\
outside the household & 3 to 11 & 1 \\
& more than 11 & 2 \\
\hline Membership in voluntary & No & 0 \\
association & 1 association & 1 \\
& more than 2 different associations & 2 \\
\hline
\end{tabular}

Source: Berkman et al. (2004).

Table A.4: Descriptive statistics for the level of social integration and corresponding distributions of the included indicators exemplarily for Wave 12

\begin{tabular}{cccccc}
\hline $\begin{array}{c}\text { Level of social } \\
\text { integration }\end{array}$ & $\begin{array}{c}\text { Average number of } \\
\text { close friends and } \\
\text { relatives outside the } \\
\text { household }\end{array}$ & $\begin{array}{c}\text { Proportion of } \\
\text { individuals } \\
\text { being married } \\
\text { or cohabited }\end{array}$ & $\begin{array}{c}\text { Proportion of } \\
\text { individuals being } \\
\text { an active member } \\
\text { in a voluntary } \\
\text { association }\end{array}$ & N & Total \\
\hline 1 & 5.1 & 0 & 0 & 1227 & 18.9 \\
2 & 8.4 & 0 & 82.51 & 732 & 11.3 \\
3 & 5.84 & 88.11 & 11.89 & 2355 & 36.3 \\
4 & 9.3 & 97.71 & 78.14 & 1395 & 21.5 \\
5 & 10.6 & 100 & 100 & 668 & 10.3 \\
6 & 23.1 & 100 & 100 & 102 & 1.6 \\
\hline Overall & 7.49 & 64.95 & 42.35 & 6479 & 100 \\
\hline
\end{tabular}

Source: PASS, Welle 12 v1 (DOI: 10.5164/IAB.PASS-SUF0618.de.en.v1), own calculation.

Figure A.1: Distribution of the number of close friends and relatives outside the household and corresponding scoring of the Social Integration Index

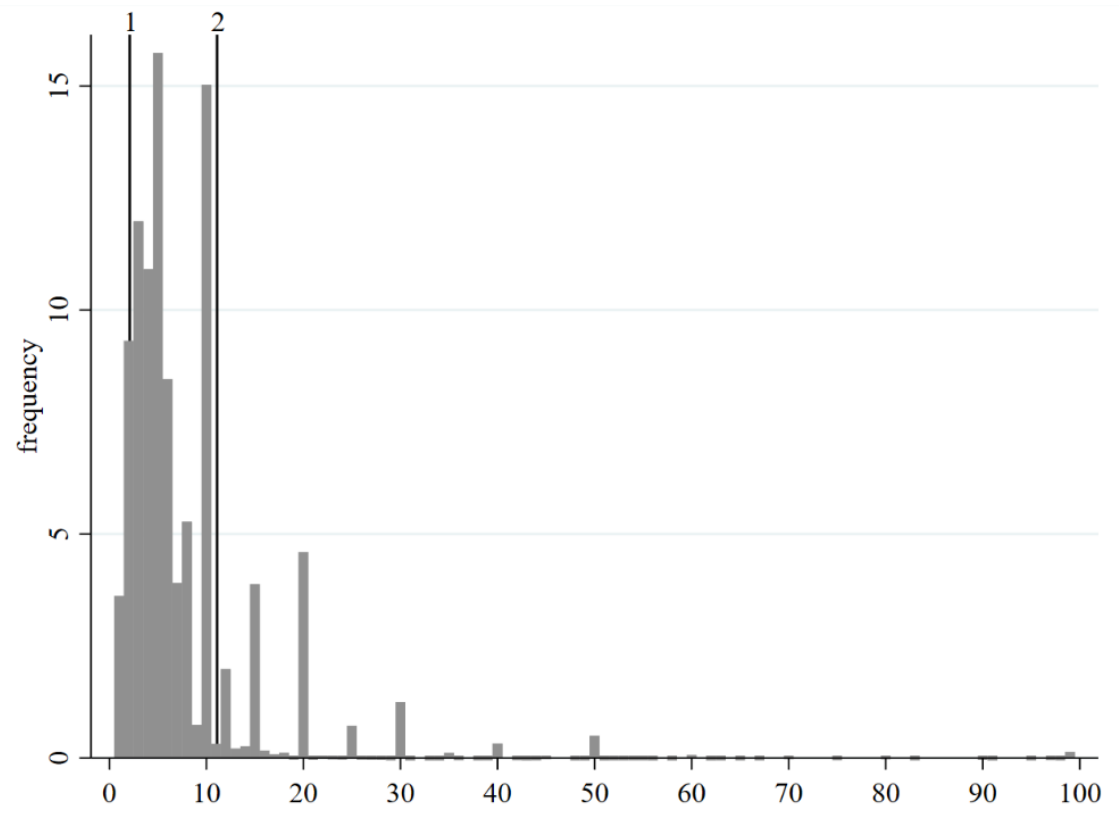

Source: PASS, Welle 12 v1 (DOI: 10.5164/IAB.PASS-SUF0618.de.en.v1), N= 77,294 (n=15,863), own calculation. 
The Intervening Role of Social Integration in the Effect of Education on Subjective Mental Health

Table A.5: Partial Correlations between main variables

\begin{tabular}{|c|c|c|c|c|c|c|c|}
\hline & $\begin{array}{l}\text { At least good } \\
\text { health }\end{array}$ & $\begin{array}{l}\text { At least good } \\
\text { mental health }\end{array}$ & $\begin{array}{c}\text { Years of } \\
\text { education }\end{array}$ & $\begin{array}{c}\text { Level of social } \\
\text { integration }\end{array}$ & $\begin{array}{l}\text { Number of } \\
\text { friends (log) }\end{array}$ & $\begin{array}{c}\text { Married or } \\
\text { cohabited }\end{array}$ & $\begin{array}{c}\text { Active membership } \\
\text { in a voluntary } \\
\text { association }\end{array}$ \\
\hline At least good health & 1 & & & & & & \\
\hline Years of education & 0.12 & 0.06 & 1 & & & & \\
\hline $\begin{array}{l}\text { Level of social } \\
\text { integration }\end{array}$ & 0.10 & 0.13 & 0.15 & 1 & & & \\
\hline $\begin{array}{l}\text { Active membership in a } \\
\text { voluntary association }\end{array}$ & 0.05 & 0.06 & 0.20 & 0.62 & 0.12 & 0.11 & 1 \\
\hline
\end{tabular}


The Intervening Role of Social Integration in the Effect of Education on Subjective Mental Health

Table A.6: RE results for the mediation of the level of social integration in the effect of education on mental health including control variables

\begin{tabular}{|c|c|c|c|}
\hline & Level of social integration & At least good mental health & At least good mental health \\
\hline Level of social integration & & & $\begin{array}{c}0.0206^{* * *} \\
(0.0018)\end{array}$ \\
\hline $\begin{array}{l}\text { Socio-economic background (ref.: parents witl } \\
\text { Medium level of education }\end{array}$ & $\begin{array}{r}\text { level of education) } \\
0.0067 \\
(0.0242)\end{array}$ & $\begin{array}{l}-0.0084 \\
(0.0076)\end{array}$ & $\begin{array}{l}-0.0085 \\
(0.0076)\end{array}$ \\
\hline Other degree & $\begin{array}{l}-0.1391 * * * \\
(0.0287)\end{array}$ & $\begin{array}{c}0.0048 \\
(0.0094)\end{array}$ & $\begin{array}{c}0.0075 \\
(0.0094)\end{array}$ \\
\hline $\begin{array}{l}\text { Age group (ref.: } 30-39 \text { ) } \\
40-49\end{array}$ & $\begin{array}{l}-0.0354^{*} \\
(0.0143)\end{array}$ & $\begin{array}{l}-0.0132 * \\
(0.0054)\end{array}$ & $\begin{array}{l}-0.0117^{*} \\
(0.0054)\end{array}$ \\
\hline West Germany & $\begin{array}{c}0.0151 \\
(0.0211)\end{array}$ & $\begin{array}{l}-0.0245^{* * *} \\
(0.0062)\end{array}$ & $\begin{array}{c}-0.0246 * * * \\
(0.0062)\end{array}$ \\
\hline Female & $\begin{array}{l}-0.2221 * * * \\
(0.0170)\end{array}$ & $\begin{array}{l}-0.1171^{* * *} \\
(0.0054)\end{array}$ & $\begin{array}{l}-0.1124 * * * \\
(0.0054)\end{array}$ \\
\hline Migration background & $\begin{array}{c}0.1073 * * * \\
(0.0200)\end{array}$ & $\begin{array}{c}0.0417 * * * \\
(0.0066)\end{array}$ & $\begin{array}{c}0.0400^{* * *} \\
(0.0065)\end{array}$ \\
\hline $\begin{array}{l}\text { Sample affiliation (ref.: general population sar } \\
\text { PASS welfare benefit recipients sample }\end{array}$ & $\begin{array}{l}-0.9310^{* * *} \\
(0.0187)\end{array}$ & $\begin{array}{l}-0.1123^{* * *} \\
(0.0059)\end{array}$ & $\begin{array}{l}-0.0929 * * * \\
(0.0061)\end{array}$ \\
\hline Number of children & $\begin{array}{l}0.1346^{* * * *} \\
(0.0054)\end{array}$ & $\begin{array}{c}0.0059 * * \\
(0.0019)\end{array}$ & $\begin{array}{c}0.0022 \\
(0.0020)\end{array}$ \\
\hline Wave 5 & $\begin{array}{l}-0.0281 * \\
(0.0139)\end{array}$ & $\begin{array}{c}0.0354 * * * \\
(0.0073)\end{array}$ & $\begin{array}{c}0.0358^{* * *} \\
(0.0073)\end{array}$ \\
\hline Wave 6 & $\begin{array}{l}-0.0042 \\
(0.0144)\end{array}$ & $\begin{array}{l}0.0172 * \\
(0.0074)\end{array}$ & $\begin{array}{l}0.0169 * \\
(0.0074)\end{array}$ \\
\hline Wave 7 & $\begin{array}{l}-0.0355^{*} \\
(0.0150)\end{array}$ & $\begin{array}{c}0.0238 * * \\
(0.0075)\end{array}$ & $\begin{array}{c}0.0241 * * \\
(0.0074)\end{array}$ \\
\hline Wave 8 & $\begin{array}{l}-0.0251 \\
(0.0156)\end{array}$ & $\begin{array}{c}0.0383 \text { **** } \\
(0.0076)\end{array}$ & $\begin{array}{c}0.0383^{* * * *} \\
(0.0076)\end{array}$ \\
\hline Wave 9 & $\begin{array}{c}0.0034 \\
(0.0162)\end{array}$ & $\begin{array}{c}0.0393^{* * * *} \\
(0.0077)\end{array}$ & $\begin{array}{c}0.0387 * * * * \\
(0.0077)\end{array}$ \\
\hline Wave 10 & $\begin{array}{c}-0.0281 \\
(0.0167)\end{array}$ & $\begin{array}{c}0.0383^{* * * *} \\
(0.0080)\end{array}$ & $\begin{array}{c}0.0382^{* * * *} \\
(0.0080)\end{array}$ \\
\hline Wave 11 & $\begin{array}{c}-0.0640 * * * \\
(0.0172)\end{array}$ & $\begin{array}{c}0.0357 * * * \\
(0.0080)\end{array}$ & $\begin{array}{c}0.0363 * * * \\
(0.0080)\end{array}$ \\
\hline Wave 12 & $\begin{array}{c}-0.0362 * \\
(0.0180)\end{array}$ & $\begin{array}{c}0.0422 * * * \\
(0.0084)\end{array}$ & $\begin{array}{c}0.0421 * * * \\
(0.0083)\end{array}$ \\
\hline Constant & $\begin{array}{c}2.9140 * * * \\
(0.0517)\end{array}$ & $\begin{array}{c}0.6760^{* * * *} \\
(0.0167)\end{array}$ & $\begin{array}{c}0.6175^{* * * *} \\
(0.0174)\end{array}$ \\
\hline
\end{tabular}

Source: PASS, Welle 12 v1 (DOI: 10.5164/IAB.PASS-SUF0618.de.en.v1), own calculation.

Note: Clustered standard errors in parentheses; ${ }^{*} p<0.05,{ }^{* *} p<0.01,{ }^{* * * *} p<0.001$, standard errors clustered by individual. 
The Intervening Role of Social Integration in the Effect of Education on Subjective Mental Health

Table A.7: RE results for the mediation of being married or cohabited in the effect of education on mental health including control variables

\begin{tabular}{|c|c|c|c|}
\hline & Married or cohabited & At least good mental health & At least good mental health \\
\hline Married or cohabited & & & $\begin{array}{c}0.0526 * * * \\
(0.0055)\end{array}$ \\
\hline \multicolumn{4}{|c|}{ Socio-economic background (ref.: parents with low level of education) } \\
\hline Medium level of education & $\begin{array}{r}-0.0024 \\
(0.0094)\end{array}$ & $\begin{array}{l}-0.0084 \\
(0.0076)\end{array}$ & $\begin{array}{l}-0.0080 \\
(0.0076)\end{array}$ \\
\hline Other degree & $\begin{array}{l}-0.0190 \\
(0.0118)\end{array}$ & $\begin{array}{c}0.0048 \\
(0.0094)\end{array}$ & $\begin{array}{c}0.0058 \\
(0.0094)\end{array}$ \\
\hline $\begin{array}{l}\text { Age group (ref.: } 30-39 \text { ) } \\
\quad 40-49\end{array}$ & $\begin{array}{c}-0.0168 * * \\
(0.0053)\end{array}$ & $\begin{array}{l}-0.0132 * \\
(0.0054)\end{array}$ & $\begin{array}{l}-0.0105 \\
(0.0054)\end{array}$ \\
\hline Female & $\begin{array}{l}-0.0532 * * * \\
(0.0066)\end{array}$ & $\begin{array}{l}-0.1171 * * * \\
(0.0054)\end{array}$ & $\begin{array}{c}-0.1139 * * * \\
(0.0054)\end{array}$ \\
\hline Migration background & $\begin{array}{c}0.1256^{* * *} \\
(0.0081)\end{array}$ & $\begin{array}{c}0.0417 * * * \\
(0.0066)\end{array}$ & $\begin{array}{c}0.0359 * * * \\
(0.0066)\end{array}$ \\
\hline \multicolumn{4}{|l|}{$\begin{array}{l}\text { Sample affiliation (ref.: general population } \\
\text { sample) }\end{array}$} \\
\hline PASS welfare benefit recipients sample & $\begin{array}{c}-0.2981 * * * \\
(0.0071)\end{array}$ & $\begin{array}{c}-0.1123 * * * \\
(0.0059)\end{array}$ & $\begin{array}{c}-0.0961 * * * \\
(0.0061)\end{array}$ \\
\hline Number of children & $\begin{array}{c}0.0504 * * * \\
(0.0022)\end{array}$ & $\begin{array}{c}0.0059^{* *} \\
(0.0019)\end{array}$ & $\begin{array}{c}0.0016 \\
(0.0020)\end{array}$ \\
\hline Wave 5 & $\begin{array}{c}-0.0037 \\
(0.0041)\end{array}$ & $\begin{array}{c}0.0354 * * * \\
(0.0073)\end{array}$ & $\begin{array}{c}0.0352 * * * \\
(0.0073)\end{array}$ \\
\hline Wave 6 & $\begin{array}{c}-0.0018 \\
(0.0044)\end{array}$ & $\begin{array}{c}0.0172 * \\
(0.0074)\end{array}$ & $\begin{array}{l}0.0167 * \\
(0.0074)\end{array}$ \\
\hline Wave 7 & $\begin{array}{c}-0.0012 \\
(0.0047)\end{array}$ & $\begin{array}{c}0.0238^{* * *} \\
(0.0075)\end{array}$ & $\begin{array}{c}0.0232 * * \\
(0.0074)\end{array}$ \\
\hline Wave 8 & $\begin{array}{l}-0.0029 \\
(0.0050)\end{array}$ & $\begin{array}{c}0.0383^{* * *} \\
(0.0076)\end{array}$ & $\begin{array}{c}0.0377 * * * \\
(0.0076)\end{array}$ \\
\hline Wave 9 & $\begin{array}{l}-0.0054 \\
(0.0053)\end{array}$ & $\begin{array}{c}0.0393 * * * \\
(0.0077)\end{array}$ & $\begin{array}{c}0.0387 * * * \\
(0.0077)\end{array}$ \\
\hline Wave 10 & $\begin{array}{c}-0.0062 \\
(0.0056)\end{array}$ & $\begin{array}{c}0.0383 * * * \\
(0.0080)\end{array}$ & $\begin{array}{c}0.0375 * * * \\
(0.0080)\end{array}$ \\
\hline Wave 11 & $\begin{array}{c}-0.0076 \\
(0.0059)\end{array}$ & $\begin{array}{c}0.0357 * * * \\
(0.0080)\end{array}$ & $\begin{array}{c}0.0349 * * * \\
(0.0080)\end{array}$ \\
\hline Wave 12 & $\begin{array}{c}-0.0085 \\
(0.0061)\end{array}$ & $\begin{array}{c}0.0422 * * * \\
(0.0084)\end{array}$ & $\begin{array}{c}0.0414 * * * \\
(0.0083)\end{array}$ \\
\hline Constant & $\begin{array}{c}0.7194 * * * \\
(0.0217)\end{array}$ & $\begin{array}{c}0.6760 * * * \\
(0.0167)\end{array}$ & $\begin{array}{c}0.6386^{* * * *} \\
(0.0171)\end{array}$ \\
\hline $\begin{array}{l}\text { Observations } \\
\mathrm{N}\end{array}$ & $\begin{array}{l}77,294 \\
15,863 \\
\end{array}$ & $\begin{array}{l}77,294 \\
15,863 \\
\end{array}$ & $\begin{array}{l}77,294 \\
15,863 \\
\end{array}$ \\
\hline
\end{tabular}

Source: PASS, Welle 12 v1 (DOI: 10.5164/IAB.PASS-SUF0618.de.en.v1), own calculation.

Note: Clustered standard errors in parentheses; ${ }^{*} p<0.05,{ }^{* *} p<0.01,{ }^{* * *} p<0.001$, standard errors clustered by individual. 
The Intervening Role of Social Integration in the Effect of Education on Subjective Mental Health

Table A.8: RE results for the mediation of the number of close friends and relatives outside the household in the effect of education on mental health including control variables

\begin{tabular}{|c|c|c|c|}
\hline & $\begin{array}{c}\text { Number of close friends and relatives } \\
\text { outside the household (ln) }\end{array}$ & At least good mental health & At least good mental health \\
\hline \multirow[t]{2}{*}{ Years of education } & $0.0157^{* * * *}$ & $0.0070^{* * *}$ & $0.0064^{* * *}$ \\
\hline & $(0.0016)$ & $(0.0011)$ & $(0.0011)$ \\
\hline $\begin{array}{l}\text { Number of close friends and relatives outside the } \\
\text { household (ln) }\end{array}$ & & & $\begin{array}{c}0.0381 * * * \\
(0.0030)\end{array}$ \\
\hline \multicolumn{4}{|c|}{ Socio-economic background (ref.: parents with low level of education) } \\
\hline Medium level of education & $\begin{array}{c}0.0353 * * \\
(0.0113)\end{array}$ & $\begin{array}{l}-0.0084 \\
(0.0076)\end{array}$ & $\begin{array}{l}-0.0098 \\
(0.0076)\end{array}$ \\
\hline Higher level of education & $\begin{array}{c}0.0441^{* * *} \\
(0.0123)\end{array}$ & $\begin{array}{l}-0.0234 * * \\
(0.0084)\end{array}$ & $\begin{array}{l}-0.0252^{* *} \\
(0.0083)\end{array}$ \\
\hline Other degree & $\begin{array}{l}-0.0354^{*} \\
(0.0144)\end{array}$ & $\begin{array}{c}0.0048 \\
(0.0094)\end{array}$ & $\begin{array}{c}0.0061 \\
(0.0094)\end{array}$ \\
\hline \multicolumn{4}{|l|}{ Age group (ref.: $30-39$ ) } \\
\hline $40-49$ & $\begin{array}{l}-0.0243 * * * \\
(0.0073)\end{array}$ & $\begin{array}{l}-0.0132 * \\
(0.0054)\end{array}$ & $\begin{array}{l}-0.0125^{*} \\
(0.0054)\end{array}$ \\
\hline $50-60$ & $\begin{array}{l}0.0183^{*} \\
(0.0085)\end{array}$ & $\begin{array}{c}-0.0198 * * \\
(0.0062)\end{array}$ & $\begin{array}{l}-0.0209 * * * \\
(0.0062)\end{array}$ \\
\hline West Germany & $\begin{array}{c}-0.0478 * * * \\
(0.0092)\end{array}$ & $\begin{array}{c}-0.0245^{* * *} \\
(0.0062)\end{array}$ & $\begin{array}{c}-0.0226^{* * * *} \\
(0.0062)\end{array}$ \\
\hline Female & $\begin{array}{l}-0.0451^{* * *} \\
(0.0082)\end{array}$ & $\begin{array}{l}-0.1171 * * * \\
(0.0054)\end{array}$ & $\begin{array}{l}-0.1155^{* * *} \\
(0.0054)\end{array}$ \\
\hline Migration background & $\begin{array}{c}0.0327 * * \\
(0.0102)\end{array}$ & $\begin{array}{c}0.0417 * * * \\
(0.0066)\end{array}$ & $\begin{array}{l}0.0404 * * * \\
(0.0065)\end{array}$ \\
\hline $\begin{array}{l}\text { Sample affiliation (ref.: general population sample) } \\
\text { PASS welfare benefit recipients sample }\end{array}$ & $\begin{array}{c}-0.0738^{* * *} \\
(0.0089)\end{array}$ & $\begin{array}{c}-0.1123^{* * *} \\
(0.0059)\end{array}$ & $\begin{array}{l}-0.1095^{* * *} \\
(0.0059)\end{array}$ \\
\hline Number of children & $\begin{array}{c}0.0146^{* * * *} \\
(0.0029)\end{array}$ & $\begin{array}{c}0.0059 * * \\
(0.0019)\end{array}$ & $\begin{array}{c}0.0054^{* *} \\
(0.0019)\end{array}$ \\
\hline $\begin{array}{l}\text { Survey wave (ref.: wave 1) } \\
\text { Wave } 2\end{array}$ & $\begin{array}{c}-0.0302 * * * \\
(0.0089)\end{array}$ & $\begin{array}{c}0.0223^{* *} \\
(0.0068)\end{array}$ & $\begin{array}{c}0.0235^{* * *} \\
(0.0068)\end{array}$ \\
\hline Wave 3 & $\begin{array}{c}-0.1207 * * * \\
(0.0092)\end{array}$ & $\begin{array}{c}0.0207 * * \\
(0.0070)\end{array}$ & $\begin{array}{c}0.0254 * * * \\
(0.0070)\end{array}$ \\
\hline Wave 4 & $\begin{array}{c}-0.1113^{* * *} \\
(0.0094)\end{array}$ & $\begin{array}{c}0.0244 * * * \\
(0.0074)\end{array}$ & $\begin{array}{c}0.0286^{* * * *} \\
(0.0074)\end{array}$ \\
\hline Wave 5 & $\begin{array}{l}-0.1558^{* * *} \\
(0.0095)\end{array}$ & $\begin{array}{l}0.0354 * * * \\
(0.0073)\end{array}$ & $\begin{array}{l}0.0411^{* * * *} \\
(0.0073)\end{array}$ \\
\hline Wave 6 & $\begin{array}{c}-0.1469 * * * \\
(0.0095)\end{array}$ & $\begin{array}{l}0.0172 * \\
(0.0074)\end{array}$ & $\begin{array}{c}0.0225^{* *} \\
(0.0074)\end{array}$ \\
\hline Wave 7 & $\begin{array}{c}-0.1699 * * * \\
(0.0096)\end{array}$ & $\begin{array}{c}0.0238 * * \\
(0.0075)\end{array}$ & $\begin{array}{c}0.0300 * * * \\
(0.0075)\end{array}$ \\
\hline Wave 8 & $\begin{array}{c}-0.1627 * * * \\
(0.0097)\end{array}$ & $\begin{array}{c}0.0383^{* * * *} \\
(0.0076)\end{array}$ & $\begin{array}{c}0.0442 * * * \\
(0.0077)\end{array}$ \\
\hline Wave 9 & $\begin{array}{c}-0.1472 * * * \\
(0.0099)\end{array}$ & $\begin{array}{c}0.0393^{* * * *} \\
(0.0077)\end{array}$ & $\begin{array}{c}0.0447 \text { *** } \\
(0.0078)\end{array}$ \\
\hline Wave 10 & $\begin{array}{c}-0.1584^{* * *} \\
(0.0100)\end{array}$ & $\begin{array}{c}0.0383^{* * * *} \\
(0.0080)\end{array}$ & $\begin{array}{c}0.0440^{* * * *} \\
(0.0080)\end{array}$ \\
\hline Wave 11 & $\begin{array}{l}-0.1645^{* * *} \\
(0.0101)\end{array}$ & $\begin{array}{c}0.0357 * * * \\
(0.0080)\end{array}$ & $\begin{array}{c}0.0416^{* * *} \\
(0.0081)\end{array}$ \\
\hline Wave 12 & $\begin{array}{c}-0.1648 * * * \\
(0.0104)\end{array}$ & $\begin{array}{c}0.0422 * * * \\
(0.0084)\end{array}$ & $\begin{array}{c}0.0480^{* * * *} \\
(0.0084)\end{array}$ \\
\hline Constant & $\begin{array}{c}1.9396^{* * * *} \\
(0.0252) \\
\end{array}$ & $\begin{array}{c}0.6760^{* * * *} \\
(0.0167) \\
\end{array}$ & $\begin{array}{c}0.6024 * * * * \\
(0.0178) \\
\end{array}$ \\
\hline $\begin{array}{l}\text { Observations } \\
\mathrm{N}\end{array}$ & $\begin{array}{l}77,294 \\
15,863 \\
\end{array}$ & $\begin{array}{l}77,294 \\
15,863 \\
\end{array}$ & $\begin{array}{l}77,294 \\
15,863 \\
\end{array}$ \\
\hline
\end{tabular}

Source: PASS, Welle 12 v1 (DOI: 10.5164/IAB.PASS-SUF0618.de.en.v1), own calculation.

Note: Clustered standard errors in parentheses; ${ }^{*} p<0.05,{ }^{* *} p<0.01,{ }^{* * *} p<0.001$, standard errors clustered by individual. 
The Intervening Role of Social Integration in the Effect of Education on Subjective Mental Health

Table A.9: RE results for the mediation of the active membership in a voluntary association in the effect of education on mental health including control variables

\begin{tabular}{|c|c|c|c|}
\hline & $\begin{array}{c}\text { Active membership in a voluntary } \\
\text { association }\end{array}$ & At least good mental health & At least good mental health \\
\hline Years in education & $\begin{array}{c}0.0247 * * * \\
(0.0012)\end{array}$ & $\begin{array}{c}0.0070^{* * * *} \\
(0.0011)\end{array}$ & $\begin{array}{c}0.0065^{* * *} \\
(0.0011)\end{array}$ \\
\hline Active membership in a voluntary association & & & $\begin{array}{c}0.0194 * * * \\
(0.0041)\end{array}$ \\
\hline \multicolumn{4}{|c|}{ Socio-economic background (ref.: parents with low level of education) } \\
\hline Medium level of education & $\begin{array}{c}0.0157 \\
(0.0089)\end{array}$ & $\begin{array}{l}-0.0084 \\
(0.0076)\end{array}$ & $\begin{array}{l}-0.0087 \\
(0.0076)\end{array}$ \\
\hline Higher level of education & $\begin{array}{c}0.0331 * * * \\
(0.0095)\end{array}$ & $\begin{array}{c}-0.0234 * * \\
(0.0084)\end{array}$ & $\begin{array}{c}-0.0240^{* *} \\
(0.0084)\end{array}$ \\
\hline Other degree & $\begin{array}{l}-0.0550 * * * \\
(0.0096)\end{array}$ & $\begin{array}{c}0.0048 \\
(0.0094)\end{array}$ & $\begin{array}{c}0.0058 \\
(0.0095)\end{array}$ \\
\hline $\begin{array}{l}\text { Age group (ref.: } 30-39 \text { ) } \\
\quad 40-49\end{array}$ & $\begin{array}{l}0.0154 * * \\
(0.0058)\end{array}$ & $\begin{array}{l}-0.0132^{*} \\
(0.0054)\end{array}$ & $\begin{array}{l}-0.0136^{*} \\
(0.0055)\end{array}$ \\
\hline $50-60$ & $\begin{array}{c}0.0304^{* * *} \\
(0.0066)\end{array}$ & $\begin{array}{c}-0.0198 * * \\
(0.0062)\end{array}$ & $\begin{array}{c}-0.0204 * * * \\
(0.0062)\end{array}$ \\
\hline West Germany & $\begin{array}{c}0.0466^{* * *} \\
(0.0072)\end{array}$ & $\begin{array}{c}-0.0245 * * * \\
(0.0062)\end{array}$ & $\begin{array}{c}-0.0254 * * * \\
(0.0062)\end{array}$ \\
\hline Female & $\begin{array}{c}-0.0565 * * * \\
(0.0061)\end{array}$ & $\begin{array}{c}-0.1171 * * * \\
(0.0054)\end{array}$ & $\begin{array}{c}-0.1160 * * * \\
(0.0054)\end{array}$ \\
\hline Migration background & $\begin{array}{c}-0.1209 * * * \\
(0.0070)\end{array}$ & $\begin{array}{c}0.0417 * * * \\
(0.0066)\end{array}$ & $\begin{array}{c}0.0441 * * * \\
(0.0066)\end{array}$ \\
\hline $\begin{array}{l}\text { Sample affiliation (ref.: general population sam } \\
\text { PASS welfare benefit recipients sample }\end{array}$ & $\begin{array}{l}-0.1941 * * * \\
(0.0069)\end{array}$ & $\begin{array}{c}-0.1123 * * * \\
(0.0059)\end{array}$ & $\begin{array}{c}-0.1086^{* * * *} \\
(0.0060)\end{array}$ \\
\hline Number of children & $\begin{array}{c}0.0016 \\
(0.0020)\end{array}$ & $\begin{array}{l}0.0059^{* *} \\
(0.0019)\end{array}$ & $\begin{array}{c}0.0059^{* *} \\
(0.0019)\end{array}$ \\
\hline $\begin{array}{l}\text { Survey wave (ref.: wave 1) } \\
\text { Wave } 2\end{array}$ & $\begin{array}{l}-0.0123^{*} \\
(0.0059)\end{array}$ & $\begin{array}{l}0.0223^{* *} \\
(0.0068)\end{array}$ & $\begin{array}{c}0.0226 * * * * \\
(0.0068)\end{array}$ \\
\hline Wave 3 & $\begin{array}{c}-0.0043 \\
(0.0061)\end{array}$ & $\begin{array}{c}0.0207 * * \\
(0.0070)\end{array}$ & $\begin{array}{c}0.0208 * * \\
(0.0070)\end{array}$ \\
\hline Wave 4 & $\begin{array}{c}0.0224 * * * \\
(0.0064)\end{array}$ & $\begin{array}{c}0.0244 * * * \\
(0.0074)\end{array}$ & $\begin{array}{c}0.0240 * * \\
(0.0074)\end{array}$ \\
\hline Wave 5 & $\begin{array}{c}0.0233 * * * \\
(0.0066)\end{array}$ & $\begin{array}{c}0.0354 * * * \\
(0.0073)\end{array}$ & $\begin{array}{c}0.0350^{* * *} \\
(0.0073)\end{array}$ \\
\hline Wave 6 & $\begin{array}{c}0.0276 * * * \\
(0.0068)\end{array}$ & $\begin{array}{l}0.0172 * \\
(0.0074)\end{array}$ & $\begin{array}{l}0.0166^{*} \\
(0.0074)\end{array}$ \\
\hline Wave 7 & $\begin{array}{c}0.0155^{*} \\
(0.0070)\end{array}$ & $\begin{array}{c}0.0238^{* *} * \\
(0.0075)\end{array}$ & $\begin{array}{c}0.0235^{* *} * \\
(0.0075)\end{array}$ \\
\hline Wave 8 & $\begin{array}{c}0.0231 * * \\
(0.0072)\end{array}$ & $\begin{array}{c}0.0383 * * * \\
(0.0076)\end{array}$ & $\begin{array}{c}0.0379 * * * \\
(0.0076)\end{array}$ \\
\hline Wave 9 & $\begin{array}{c}0.0398^{* * *} \\
(0.0074)\end{array}$ & $\begin{array}{c}0.0393 * * * \\
(0.0077)\end{array}$ & $\begin{array}{c}0.0386^{* * * *} \\
(0.0077)\end{array}$ \\
\hline Wave 10 & $\begin{array}{c}0.0275^{* * *} \\
(0.0075)\end{array}$ & $\begin{array}{c}0.0383 * * * * \\
(0.0080)\end{array}$ & $\begin{array}{c}0.0377 * * * \\
(0.0080)\end{array}$ \\
\hline Wave 11 & $\begin{array}{c}0.0012 \\
(0.0077)\end{array}$ & $\begin{array}{c}0.0357 * * * * \\
(0.0080)\end{array}$ & $\begin{array}{c}0.0357 * * * \\
(0.0080)\end{array}$ \\
\hline Wave 12 & $\begin{array}{c}0.0247 * * \\
(0.0081)\end{array}$ & $\begin{array}{c}0.0422^{* * * *} \\
(0.0084)\end{array}$ & $\begin{array}{c}0.0417 * * * \\
(0.0084)\end{array}$ \\
\hline Constant & $\begin{array}{c}0.2298 * * * \\
(0.0187) \\
\end{array}$ & $\begin{array}{c}0.6760^{* * * *} \\
(0.0167)\end{array}$ & $\begin{array}{c}0.6716^{* * * *} \\
(0.0167)\end{array}$ \\
\hline $\begin{array}{l}\text { Observations } \\
\mathrm{N}\end{array}$ & $\begin{array}{l}77,294 \\
15,863 \\
\end{array}$ & $\begin{array}{l}77,294 \\
15,863 \\
\end{array}$ & $\begin{array}{l}77,294 \\
15,863 \\
\end{array}$ \\
\hline
\end{tabular}

Source: PASS, Welle 12 v1 (DOI: 10.5164/IAB.PASS-SUF0618.de.en.v1), own calculation.

Note: Clustered standard errors in parentheses; ${ }^{*} p<0.05,{ }^{* *} p<0.01,{ }^{* * * *} p<0.001$, standard errors clustered by individual. 
The Intervening Role of Social Integration in the Effect of Education on Subjective Mental Health

Table A.10: FE results for the effect of mediators on mental health including control variables

\begin{tabular}{|c|c|c|c|c|}
\hline & At least good mental health & At least good mental health & At least good mental health & At least good mental health \\
\hline $\begin{array}{l}\text { Level of social } \\
\text { integration }\end{array}$ & $\begin{array}{c}0.00683^{* *} \\
(0.0025)\end{array}$ & & & \\
\hline Married or cohabited & & $\begin{array}{l}0.00334 \\
(0.0094)\end{array}$ & & \\
\hline \multicolumn{2}{|c|}{$\begin{array}{l}\text { Number of close friends and } \\
\text { relatives outside the household (ln) }\end{array}$} & & $\begin{array}{l}0.0204^{* * *} \\
(0.0037)\end{array}$ & \\
\hline $\begin{array}{l}\text { Membership in a } \\
\text { voluntary association }\end{array}$ & & & & $\begin{array}{l}0.0126^{*} \\
(0.0050)\end{array}$ \\
\hline Years of education & $\begin{array}{l}0.00371 \\
(0.0070)\end{array}$ & $\begin{array}{l}0.00386 \\
(0.0070)\end{array}$ & $\begin{array}{l}0.00376 \\
(0.0070)\end{array}$ & $\begin{array}{l}0.00374 \\
(0.0070)\end{array}$ \\
\hline $\begin{array}{l}\text { Age group (ref.: 30-39) } \\
\quad 40-49\end{array}$ & $\begin{array}{l}-0.0108 \\
(0.0087)\end{array}$ & $\begin{array}{l}-0.0108 \\
(0.0087)\end{array}$ & $\begin{array}{l}-0.00996 \\
(0.00873)\end{array}$ & $\begin{array}{c}-0.0109 \\
(0.00874)\end{array}$ \\
\hline $50-60$ & $\begin{array}{l}-0.0216 \\
(0.0126)\end{array}$ & $\begin{array}{l}-0.0215 \\
(0.0126)\end{array}$ & $\begin{array}{l}-0.0212 \\
(0.0126)\end{array}$ & $\begin{array}{l}-0.0217 \\
(0.0126)\end{array}$ \\
\hline West Germany & $\begin{array}{c}0.0195 \\
(0.0315)\end{array}$ & $\begin{array}{c}0.0200 \\
(0.0315)\end{array}$ & $\begin{array}{c}0.0196 \\
(0.0315)\end{array}$ & $\begin{array}{c}0.0209 \\
(0.0315)\end{array}$ \\
\hline Number of children & $\begin{array}{l}-0.00842^{*} \\
(0.00402)\end{array}$ & $\begin{array}{l}-0.00811^{*} \\
(0.00403)\end{array}$ & $\begin{array}{l}-0.00817^{*} \\
(0.00402)\end{array}$ & $\begin{array}{l}-0.00805^{*} \\
(0.00402)\end{array}$ \\
\hline \multicolumn{5}{|l|}{$\begin{array}{l}\text { Survey wave (ref.: wave } \\
\text { 1) }\end{array}$} \\
\hline Wave 2 & $\begin{array}{l}0.0226^{* *} \\
(0.0069)\end{array}$ & $\begin{array}{l}0.0223^{* *} \\
(0.0069)\end{array}$ & $\begin{array}{l}0.0229^{* * *} \\
(0.0069)\end{array}$ & $\begin{array}{l}0.0224^{* *} \\
(0.0069)\end{array}$ \\
\hline Wave 3 & $\begin{array}{l}0.0211^{* *} \\
(0.0072)\end{array}$ & $\begin{array}{l}0.0207^{* *} \\
(0.0072)\end{array}$ & $\begin{array}{l}0.0231^{* *} \\
(0.0072)\end{array}$ & $\begin{array}{l}0.0207^{* *} \\
(0.0072)\end{array}$ \\
\hline Wave 4 & $\begin{array}{l}0.0294^{* * *} \\
(0.0078)\end{array}$ & $\begin{array}{l}0.0293^{* * *} \\
(0.0078)\end{array}$ & $\begin{array}{l}0.0315^{* * *} \\
(0.0078)\end{array}$ & $\begin{array}{l}0.0289^{* * *} \\
(0.0078)\end{array}$ \\
\hline Wave 5 & $\begin{array}{c}0.0447^{* * *} \\
(0.0080)\end{array}$ & $\begin{array}{c}0.0444^{* * *} \\
(0.0080)\end{array}$ & $\begin{array}{c}0.0477^{* * *} \\
(0.0080)\end{array}$ & $\begin{array}{l}0.0441^{* * *} \\
(0.0080)\end{array}$ \\
\hline Wave 6 & $\begin{array}{l}0.0278^{* * *} \\
(0.0083)\end{array}$ & $\begin{array}{l}0.0277^{* * *} \\
(0.0083)\end{array}$ & $\begin{array}{l}0.0308^{* * *} \\
(0.0083)\end{array}$ & $\begin{array}{l}0.0273^{* *} \\
(0.0083)\end{array}$ \\
\hline Wave 7 & $\begin{array}{l}0.0370^{* * *} \\
(0.0085)\end{array}$ & $\begin{array}{c}0.0367^{* * *} \\
(0.0085)\end{array}$ & $\begin{array}{c}0.0402^{* * *} \\
(0.0086)\end{array}$ & $\begin{array}{l}0.0364^{* * *} \\
(0.00852)\end{array}$ \\
\hline Wave 8 & $\begin{array}{l}0.0542^{* * *} \\
(0.00894)\end{array}$ & $\begin{array}{l}0.0540^{* * *} \\
(0.00894)\end{array}$ & $\begin{array}{l}0.0574^{* * *} \\
(0.00896)\end{array}$ & $\begin{array}{c}0.0537^{* * * *} \\
(0.0089)\end{array}$ \\
\hline Wave 9 & $\begin{array}{c}0.0557^{* * *} \\
(0.0093)\end{array}$ & $\begin{array}{c}0.0557^{* * *} \\
(0.0093)\end{array}$ & $\begin{array}{c}0.0586^{* * *} \\
(0.0093)\end{array}$ & $\begin{array}{c}0.0550^{* * * *} \\
(0.0093)\end{array}$ \\
\hline Wave 10 & $\begin{array}{c}0.0565^{* * *} \\
(0.0097)\end{array}$ & $\begin{array}{c}0.0563^{* * *} \\
(0.0097)\end{array}$ & $\begin{array}{c}0.0595^{* * *} \\
(0.0097)\end{array}$ & $\begin{array}{l}0.0558^{* * *} \\
(0.0097)\end{array}$ \\
\hline Wave 11 & $\begin{array}{c}0.0554^{* * *} \\
(0.0102)\end{array}$ & $\begin{array}{c}0.0548^{* * *} \\
(0.0102)\end{array}$ & $\begin{array}{c}0.0583^{* * *} \\
(0.0102)\end{array}$ & $\begin{array}{c}0.0547^{* * *} \\
(0.0102)\end{array}$ \\
\hline Wave 12 & $\begin{array}{c}0.0636^{* * *} \\
(0.0107)\end{array}$ & $\begin{array}{c}0.0633^{* * *} \\
(0.0107)\end{array}$ & $\begin{array}{c}0.0667^{* * *} \\
(0.0107)\end{array}$ & $\begin{array}{c}0.0629^{\text {**** }} \\
(0.0107)\end{array}$ \\
\hline Constant & $\begin{array}{l}0.551^{* * * *} \\
(0.0893)\end{array}$ & $\begin{array}{l}0.567^{* * * *} \\
(0.0891)\end{array}$ & $\begin{array}{l}0.528^{* * * *} \\
(0.0894)\end{array}$ & $\begin{array}{l}0.565^{* * * *} \\
(0.0889) \\
\end{array}$ \\
\hline$N$ & $\begin{array}{l}77,294 \\
15,863\end{array}$ & $\begin{array}{l}77,294 \\
15,863\end{array}$ & $\begin{array}{l}77,294 \\
15,863\end{array}$ & $\begin{array}{l}77,294 \\
15,863\end{array}$ \\
\hline
\end{tabular}

Source: PASS, Welle 12 v1 (DOI: 10.5164/IAB.PASS-SUF0618.de.en.v1), own calculation.

Note: Clustered standard errors in parentheses; ${ }^{*} p<0.05,{ }^{* * *} p<0.01,{ }^{* * * *} p<0.001$, standard errors clustered by individual. 
The Intervening Role of Social Integration in the Effect of Education on Subjective Mental Health

Table A.11: RE results for the mediation of the level of social integration in the effect of education on overall health status including control variables

\begin{tabular}{|c|c|c|c|}
\hline & Level of social integration & At least good overall health & At least good overall health \\
\hline Years of education & $\begin{array}{c}0.0469^{* * *} \\
(0.0033)\end{array}$ & $\begin{array}{c}0.0154^{* * *} \\
(0.0011)\end{array}$ & $\begin{array}{c}0.0147^{* * *} \\
(0.0011)\end{array}$ \\
\hline Level of social integration & & & $\begin{array}{c}0.0121 * * * \\
(0.0019)\end{array}$ \\
\hline \multicolumn{4}{|c|}{ Socio-economic background (ref.: parents with low levels of education) } \\
\hline Medium level of education & $\begin{array}{c}0.0067 \\
(0.0242)\end{array}$ & $\begin{array}{c}0.0059 \\
(0.0080)\end{array}$ & $\begin{array}{c}0.0058 \\
(0.0080)\end{array}$ \\
\hline Higher level of education & $\begin{array}{l}-0.0448 \\
(0.0264)\end{array}$ & $\begin{array}{c}0.0166 \\
(0.0087)\end{array}$ & $\begin{array}{l}0.0171^{*} \\
(0.0087)\end{array}$ \\
\hline Other degree & $\begin{array}{l}-0.1391 * * * \\
(0.0287)\end{array}$ & $\begin{array}{c}-0.0099 \\
(0.0096)\end{array}$ & $\begin{array}{l}-0.0083 \\
(0.0095)\end{array}$ \\
\hline $\begin{array}{l}\text { Age group (ref.: } 30-39) \\
40-49\end{array}$ & $\begin{array}{c}-0.0354^{*} \\
(0.0143)\end{array}$ & $\begin{array}{c}-0.0616^{* * * *} \\
(0.0059)\end{array}$ & $\begin{array}{l}-0.0607 * * * \\
(0.0058)\end{array}$ \\
\hline $50-60$ & $\begin{array}{l}-0.0213 \\
(0.0166)\end{array}$ & $\begin{array}{l}-0.1346^{* * * *} \\
(0.0064)\end{array}$ & $\begin{array}{l}-0.1341^{* * *} \\
(0.0064)\end{array}$ \\
\hline West Germany & $\begin{array}{c}0.0151 \\
(0.0211)\end{array}$ & $\begin{array}{c}-0.0337 * * * \\
(0.0064)\end{array}$ & $\begin{array}{c}-0.0338^{* * *} \\
(0.0064)\end{array}$ \\
\hline Female & $\begin{array}{c}-0.2221 * * * \\
(0.0170)\end{array}$ & $\begin{array}{c}-0.0641 * * * \\
(0.0056)\end{array}$ & $\begin{array}{c}-0.0613 * * * \\
(0.0057)\end{array}$ \\
\hline Migration background & $\begin{array}{c}0.1073 * * * \\
(0.0200)\end{array}$ & $\begin{array}{c}0.0391 * * * \\
(0.0068)\end{array}$ & $\begin{array}{l}0.0380 * * * \\
(0.0068)\end{array}$ \\
\hline $\begin{array}{l}\text { Sample affiliation (ref.: general population sar } \\
\text { PASS welfare benefit recipients sample }\end{array}$ & $\begin{array}{l}-0.9310^{* * *} \\
(0.0187)\end{array}$ & $\begin{array}{l}-0.1168 * * * \\
(0.0061)\end{array}$ & $\begin{array}{l}-0.1054 * * * \\
(0.0064)\end{array}$ \\
\hline Number of children & $\begin{array}{c}0.1346^{* * *} \\
(0.0054)\end{array}$ & $\begin{array}{c}0.0036 \\
(0.0020)\end{array}$ & $\begin{array}{c}0.0015 \\
(0.0020)\end{array}$ \\
\hline $\begin{array}{l}\text { Survey wave (ref.: wave 1) } \\
\text { Wave } 2\end{array}$ & $\begin{array}{l}-0.0516^{* * *} \\
(0.0113)\end{array}$ & $\begin{array}{l}-0.0138 \\
(0.0071)\end{array}$ & $\begin{array}{l}-0.0131 \\
(0.0071)\end{array}$ \\
\hline Wave 3 & $\begin{array}{l}-0.0587 * * * \\
(0.0121)\end{array}$ & $\begin{array}{l}-0.0333 * * * \\
(0.0072)\end{array}$ & $\begin{array}{c}-0.0324 * * * \\
(0.0072)\end{array}$ \\
\hline Wave 4 & $\begin{array}{l}-0.0165 \\
(0.0134)\end{array}$ & $\begin{array}{c}-0.0215^{* *} \\
(0.0075)\end{array}$ & $\begin{array}{c}-0.0212^{* *} * \\
(0.0075)\end{array}$ \\
\hline Wave 5 & $\begin{array}{c}-0.0281^{*} \\
(0.0139)\end{array}$ & $\begin{array}{c}-0.0239 * * \\
(0.0075)\end{array}$ & $\begin{array}{c}-0.0236^{* *} \\
(0.0075)\end{array}$ \\
\hline Wave 6 & $\begin{array}{c}-0.0042 \\
(0.0144)\end{array}$ & $\begin{array}{c}-0.0366^{* * * *} \\
(0.0075)\end{array}$ & $\begin{array}{c}-0.0367 * * * \\
(0.0075)\end{array}$ \\
\hline Wave 7 & $\begin{array}{c}-0.0355^{*} \\
(0.0150)\end{array}$ & $\begin{array}{c}-0.0805^{* * *} * \\
(0.0076)\end{array}$ & $\begin{array}{c}-0.0803 * * * \\
(0.0076)\end{array}$ \\
\hline Wave 8 & $\begin{array}{c}-0.0251 \\
(0.0156)\end{array}$ & $\begin{array}{c}-0.0576 * * * \\
(0.0078)\end{array}$ & $\begin{array}{c}-0.0574 * * * * \\
(0.0078)\end{array}$ \\
\hline Wave 9 & $\begin{array}{c}0.0034 \\
(0.0162)\end{array}$ & $\begin{array}{c}-0.0657 * * * \\
(0.0080)\end{array}$ & $\begin{array}{c}-0.0660 * * * \\
(0.0080)\end{array}$ \\
\hline Wave 10 & $\begin{array}{l}-0.0281 \\
(0.0167)\end{array}$ & $\begin{array}{c}-0.0743 * * * \\
(0.0082)\end{array}$ & $\begin{array}{c}-0.0741^{* * *} * \\
(0.0082)\end{array}$ \\
\hline Wave 11 & $\begin{array}{c}-0.0640^{* * * *} \\
(0.0172)\end{array}$ & $\begin{array}{c}-0.0604 * * * \\
(0.0082)\end{array}$ & $\begin{array}{c}-0.0600 * * * * \\
(0.0082)\end{array}$ \\
\hline Wave 12 & $\begin{array}{l}-0.0362 * \\
(0.0180)\end{array}$ & $\begin{array}{c}-0.0803 * * * \\
(0.0086)\end{array}$ & $\begin{array}{c}-0.0801 * * * \\
(0.0086)\end{array}$ \\
\hline Constant & $\begin{array}{c}2.9140 \text { *** } \\
(0.0517) \\
\end{array}$ & $\begin{array}{c}0.4884 * * * \\
(0.0176) \\
\end{array}$ & $\begin{array}{c}0.4541 \text { *** } \\
(0.0183) \\
\end{array}$ \\
\hline $\begin{array}{l}\text { Observations } \\
\mathrm{N}\end{array}$ & $\begin{array}{l}77,294 \\
15,863 \\
\end{array}$ & $\begin{array}{l}77,294 \\
15,863 \\
\end{array}$ & $\begin{array}{l}77,294 \\
15,863 \\
\end{array}$ \\
\hline
\end{tabular}

Source: PASS, Welle 12 v1 (DOI: 10.5164/IAB.PASS-SUF0618.de.en.v1), own calculation.

Note: Clustered standard errors in parentheses; ${ }^{*} p<0.05,{ }^{* *} p<0.01,{ }^{* * *} p<0.001$, standard errors clustered by individual. 
The Intervening Role of Social Integration in the Effect of Education on Subjective Mental Health

Table A.12: RE results for the mediation of being married or cohabited in the effect of education on overall health status including control variables

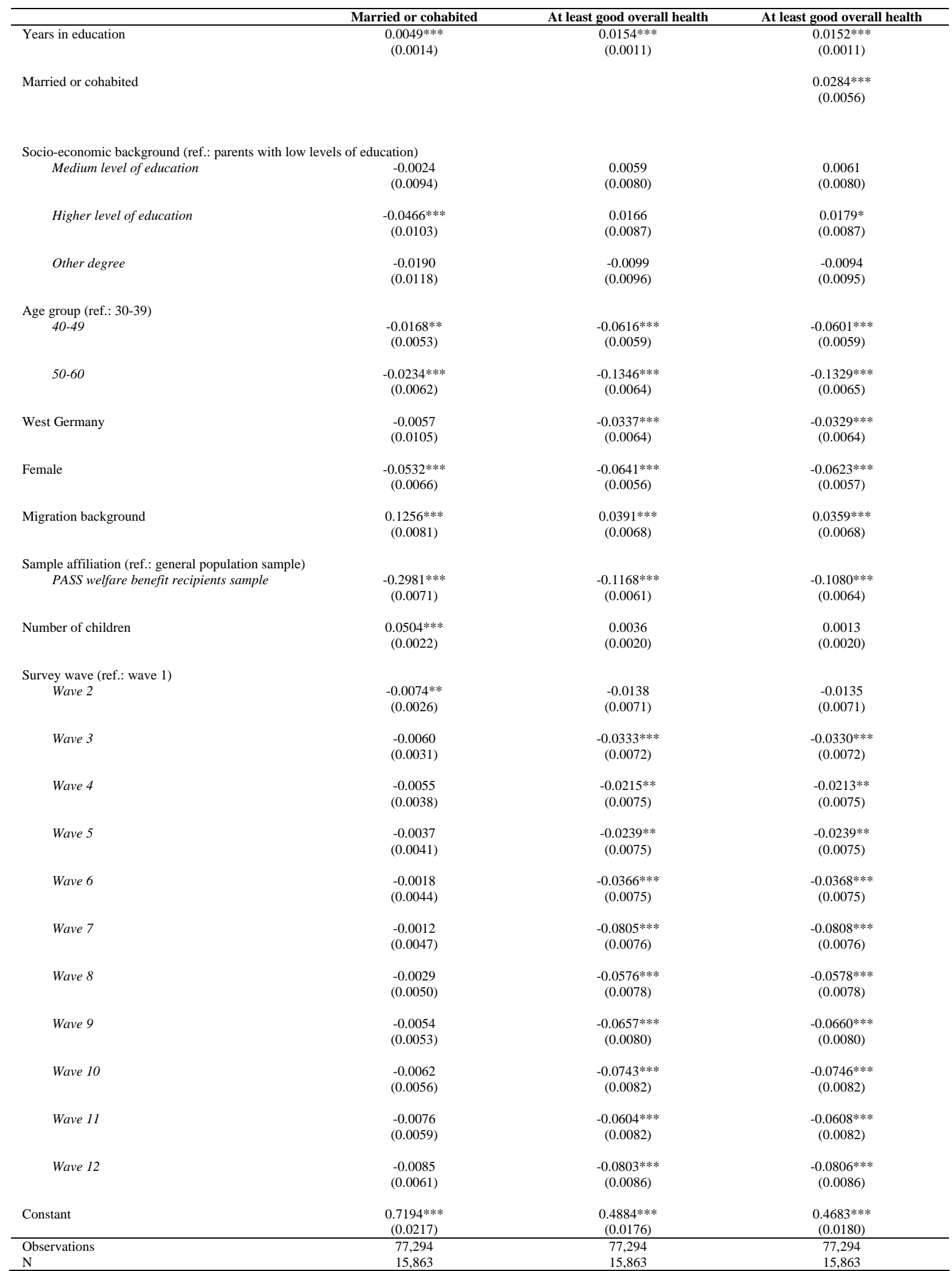

Source: PASS, Welle 12 v1 (DOI: 10.5164/IAB.PASS-SUF0618.de.en.v1), own calculation.

Note: Clustered standard errors in parentheses; ${ }^{*} p<0.05,{ }^{* *} p<0.01,{ }^{* * *} p<0.001$, standard errors clustered by individual. 
The Intervening Role of Social Integration in the Effect of Education on Subjective Mental Health

Table A.13: RE results for the mediation of the number of close friends and relatives outside the household in the effect of education on overall health status including control variables

\begin{tabular}{|c|c|c|c|}
\hline & $\begin{array}{l}\text { Number of close friends and } \\
\text { relatives outside the household (ln) }\end{array}$ & At least good overall health & At least good overall health \\
\hline Years of education & $\begin{array}{c}0.0157 * * * \\
(0.0016)\end{array}$ & $\begin{array}{l}0.0154^{* * *} \\
(0.0011)\end{array}$ & $\begin{array}{l}0.0149^{* * *} \\
(0.0011)\end{array}$ \\
\hline $\begin{array}{l}\text { Number of close friends and relatives outside the } \\
\text { household (ln) }\end{array}$ & & & $\begin{array}{c}0.0272 * * * \\
(0.0031)\end{array}$ \\
\hline $\begin{array}{l}\text { Socio-economic background (ref.: parents with low leve } \\
\text { Medium level of education }\end{array}$ & $\begin{array}{l}\text { of education) } \\
\qquad \begin{array}{l}0.0353^{* *} \\
(0.0113)\end{array}\end{array}$ & $\begin{array}{c}0.0059 \\
(0.0080)\end{array}$ & $\begin{array}{c}0.0049 \\
(0.0080)\end{array}$ \\
\hline Higher level of education & $\begin{array}{c}0.0441^{* * * *} \\
(0.0123)\end{array}$ & $\begin{array}{c}0.0166 \\
(0.0087)\end{array}$ & $\begin{array}{c}0.0153 \\
(0.0087)\end{array}$ \\
\hline Other degree & $\begin{array}{l}-0.0354^{*} \\
(0.0144)\end{array}$ & $\begin{array}{l}-0.0099 \\
(0.0096)\end{array}$ & $\begin{array}{l}-0.0090 \\
(0.0095)\end{array}$ \\
\hline $\begin{array}{l}\text { Age group (ref.: } 30-39 \text { ) } \\
\quad 40-49\end{array}$ & $\begin{array}{l}-0.0243 * * * \\
(0.0073)\end{array}$ & $\begin{array}{l}-0.0616^{* * * *} \\
(0.0059)\end{array}$ & $\begin{array}{l}-0.0611 * * * \\
(0.0058)\end{array}$ \\
\hline $50-60$ & $\begin{array}{l}0.0183 * \\
(0.0085)\end{array}$ & $\begin{array}{l}-0.1346^{* * *} \\
(0.0064)\end{array}$ & $\begin{array}{l}-0.1356 * * * \\
(0.0064)\end{array}$ \\
\hline West Germany & $\begin{array}{c}-0.0478^{* * *} \\
(0.0092)\end{array}$ & $\begin{array}{c}-0.0337 * * * \\
(0.0064)\end{array}$ & $\begin{array}{c}-0.0324 * * * \\
(0.0064)\end{array}$ \\
\hline Female & $\begin{array}{l}-0.0451 * * * \\
(0.0082)\end{array}$ & $\begin{array}{l}-0.0641 * * * \\
(0.0056)\end{array}$ & $\begin{array}{l}-0.0629 * * * \\
(0.0056)\end{array}$ \\
\hline Migration background & $\begin{array}{c}0.0327 * * \\
(0.0102)\end{array}$ & $\begin{array}{c}0.0391 * * * \\
(0.0068)\end{array}$ & $\begin{array}{c}0.0381 * * * \\
(0.0068)\end{array}$ \\
\hline $\begin{array}{l}\text { Sample affiliation (ref.: general population sample) } \\
\text { PASS welfare benefit recipients sample }\end{array}$ & $\begin{array}{c}-0.0738^{* * *} \\
(0.0089)\end{array}$ & $\begin{array}{l}-0.1168 * * * \\
(0.0061)\end{array}$ & $\begin{array}{l}-0.1148 * * * \\
(0.0061)\end{array}$ \\
\hline Number of children & $\begin{array}{c}0.0146^{* * * *} \\
(0.0029)\end{array}$ & $\begin{array}{c}0.0036 \\
(0.0020)\end{array}$ & $\begin{array}{c}0.0033 \\
(0.0020)\end{array}$ \\
\hline $\begin{array}{l}\text { Survey wave (ref.: wave } 1 \text { ) } \\
\text { Wave } 2\end{array}$ & $\begin{array}{l}-0.0302 * * * \\
(0.0089)\end{array}$ & $\begin{array}{l}-0.0138 \\
(0.0071)\end{array}$ & $\begin{array}{c}-0.0129 \\
(0.0071)\end{array}$ \\
\hline Wave 3 & $\begin{array}{l}-0.1207 * * * \\
(0.0092)\end{array}$ & $\begin{array}{l}-0.0333 * * * \\
(0.0072)\end{array}$ & $\begin{array}{l}-0.0300^{* * *} \\
(0.0073)\end{array}$ \\
\hline Wave 4 & $\begin{array}{l}-0.1113^{* * *} \\
(0.0094)\end{array}$ & $\begin{array}{l}-0.0215^{* *} \\
(0.0075)\end{array}$ & $\begin{array}{l}-0.0184^{*} \\
(0.0075)\end{array}$ \\
\hline Wave 5 & $\begin{array}{l}-0.1558^{* * *} \\
(0.0095)\end{array}$ & $\begin{array}{l}-0.0239^{* *} \\
(0.0075)\end{array}$ & $\begin{array}{c}-0.0197 * * \\
(0.0075)\end{array}$ \\
\hline Wave 6 & $\begin{array}{l}-0.1469 * * * \\
(0.0095)\end{array}$ & $\begin{array}{l}-0.0366 * * * \\
(0.0075)\end{array}$ & $\begin{array}{l}-0.0327 * * * \\
(0.0075)\end{array}$ \\
\hline Wave 7 & $\begin{array}{l}-0.1699 * * * \\
(0.0096)\end{array}$ & $\begin{array}{l}-0.0805^{* * *} \\
(0.0076)\end{array}$ & $\begin{array}{l}-0.0760^{* * * *} \\
(0.0077)\end{array}$ \\
\hline Wave 8 & $\begin{array}{l}-0.1627 * * * \\
(0.0097)\end{array}$ & $\begin{array}{c}-0.0576^{* * *} \\
(0.0078)\end{array}$ & $\begin{array}{c}-0.0532 * * * \\
(0.0078)\end{array}$ \\
\hline Wave 9 & $\begin{array}{c}-0.1472 * * * \\
(0.0099)\end{array}$ & $\begin{array}{c}-0.0657 * * * \\
(0.0080)\end{array}$ & $\begin{array}{c}-0.0618^{* * * *} \\
(0.0080)\end{array}$ \\
\hline Wave 10 & $\begin{array}{c}-0.1584 * * * * \\
(0.0100)\end{array}$ & $\begin{array}{c}-0.0743 * * * \\
(0.0082)\end{array}$ & $\begin{array}{c}-0.0700^{* * * *} \\
(0.0082)\end{array}$ \\
\hline Wave 11 & $\begin{array}{c}-0.1645^{* * * *} \\
(0.0101)\end{array}$ & $\begin{array}{c}-0.0604 * * * \\
(0.0082)\end{array}$ & $\begin{array}{c}-0.0560^{* * * *} \\
(0.0082)\end{array}$ \\
\hline Wave 12 & $\begin{array}{c}-0.1648 * * * \\
(0.0104)\end{array}$ & $\begin{array}{c}-0.0803 * * * * \\
(0.0086)\end{array}$ & $\begin{array}{c}-0.0758^{* * * *} \\
(0.0086)\end{array}$ \\
\hline Constant & $\begin{array}{c}1.9396 * * * \\
(0.0252)\end{array}$ & $\begin{array}{c}0.4884 * * * \\
(0.0176)\end{array}$ & $\begin{array}{c}0.4358^{* * * *} \\
(0.0185)\end{array}$ \\
\hline $\begin{array}{l}\text { Observations } \\
\mathrm{N}\end{array}$ & $\begin{array}{l}77,294 \\
15,863\end{array}$ & $\begin{array}{l}77,294 \\
15,863\end{array}$ & $\begin{array}{l}77,294 \\
15,863\end{array}$ \\
\hline
\end{tabular}

Source: PASS, Welle 12 v1 (DOI: 10.5164/IAB.PASS-SUF0618.de.en.v1), own calculation.

Note: Clustered standard errors in parentheses; ${ }^{*} p<0.05,{ }^{* *} p<0.01,{ }^{* * *} p<0.001$, standard errors clustered by individual. 
The Intervening Role of Social Integration in the Effect of Education on Subjective Mental Health

Table A.14: RE results for the mediation of the active membership in a voluntary association in the effect of education on overall health status including control variables

\begin{tabular}{|c|c|c|c|}
\hline & $\begin{array}{l}\text { Active membership in a } \\
\text { voluntary association }\end{array}$ & At least good overall health & At least good overall health \\
\hline Years in education & $\begin{array}{l}0.0247 * * * \\
(0.0012)\end{array}$ & $\begin{array}{l}0.0154 * * * \\
(0.0011)\end{array}$ & $\begin{array}{l}0.0150^{* * * *} \\
(0.0011)\end{array}$ \\
\hline $\begin{array}{l}\text { Active membership in a } \\
\text { voluntary association }\end{array}$ & & & $\begin{array}{c}0.0129 * * \\
(0.0042)\end{array}$ \\
\hline \multicolumn{4}{|c|}{ Socio-economic background (ref.: parents with low levels of education) } \\
\hline Middle level of education & $\begin{array}{c}0.0157 \\
(0.0089)\end{array}$ & $\begin{array}{c}0.0059 \\
(0.0080)\end{array}$ & $\begin{array}{c}0.0057 \\
(0.0080)\end{array}$ \\
\hline Higher level of education & $\begin{array}{c}0.0331^{* * *} \\
(0.0095)\end{array}$ & $\begin{array}{c}0.0166 \\
(0.0087)\end{array}$ & $\begin{array}{c}0.0161 \\
(0.0087)\end{array}$ \\
\hline Other degree & $\begin{array}{c}-0.0550^{* * *} \\
(0.0096)\end{array}$ & $\begin{array}{l}-0.0099 \\
(0.0096)\end{array}$ & $\begin{array}{l}-0.0092 \\
(0.0096)\end{array}$ \\
\hline $\begin{array}{l}\text { Age group (ref.: } 30-39) \\
40-49\end{array}$ & $\begin{array}{c}0.0154^{* *} \\
(0.0058)\end{array}$ & $\begin{array}{l}-0.0616^{* * *} \\
(0.0059)\end{array}$ & $\begin{array}{l}-0.0618^{* * *} \\
(0.0059)\end{array}$ \\
\hline $50-60$ & $\begin{array}{c}0.0304 * * * \\
(0.0066)\end{array}$ & $\begin{array}{c}-0.1346^{* * *} \\
(0.0064)\end{array}$ & $\begin{array}{c}-0.1351 * * * \\
(0.0064)\end{array}$ \\
\hline West Germany & $\begin{array}{c}0.0466 * * * \\
(0.0072)\end{array}$ & $\begin{array}{c}-0.0337 * * * \\
(0.0064)\end{array}$ & $\begin{array}{c}-0.0344 * * * \\
(0.0064)\end{array}$ \\
\hline Female & $\begin{array}{c}-0.0565^{* * *} \\
(0.0061)\end{array}$ & $\begin{array}{c}-0.0641^{* * *} \\
(0.0056)\end{array}$ & $\begin{array}{c}-0.0633^{* * *} \\
(0.0056)\end{array}$ \\
\hline Migration background & $\begin{array}{l}-0.1209 * * * \\
(0.0070)\end{array}$ & $\begin{array}{c}0.0391 * * * \\
(0.0068)\end{array}$ & $\begin{array}{c}0.0406 * * * \\
(0.0068)\end{array}$ \\
\hline \multicolumn{4}{|l|}{$\begin{array}{l}\text { Sample affiliation (ref.: general } \\
\text { population sample) }\end{array}$} \\
\hline $\begin{array}{l}\text { PASS welfare benefit } \\
\text { recipients sample }\end{array}$ & $\begin{array}{c}-0.1941 * * * \\
(0.0069)\end{array}$ & $\begin{array}{c}-0.1168^{* * *} \\
(0.0061)\end{array}$ & $\begin{array}{c}-0.1143 * * * \\
(0.0062)\end{array}$ \\
\hline Number of children & $\begin{array}{c}0.0016 \\
(0.0020)\end{array}$ & $\begin{array}{c}0.0036 \\
(0.0020)\end{array}$ & $\begin{array}{c}0.0036 \\
(0.0020)\end{array}$ \\
\hline $\begin{array}{l}\text { Survey wave (ref.: wave 1) } \\
\text { Wave } 2\end{array}$ & $\begin{array}{l}-0.0123^{*} \\
(0.0059)\end{array}$ & $\begin{array}{l}-0.0138 \\
(0.0071)\end{array}$ & $\begin{array}{l}-0.0136 \\
(0.0071)\end{array}$ \\
\hline Wave 3 & $\begin{array}{l}-0.0043 \\
(0.0061)\end{array}$ & $\begin{array}{c}-0.0333^{* * *} \\
(0.0072)\end{array}$ & $\begin{array}{c}-0.0332 * * * \\
(0.0072)\end{array}$ \\
\hline Wave 4 & $\begin{array}{c}0.0224 * * * \\
(0.0064)\end{array}$ & $\begin{array}{c}-0.0215^{* *} \\
(0.0075)\end{array}$ & $\begin{array}{c}-0.0217 * * \\
(0.0075)\end{array}$ \\
\hline Wave 5 & $\begin{array}{c}0.0233 * * * \\
(0.0066)\end{array}$ & $\begin{array}{c}-0.0239 * * \\
(0.0075)\end{array}$ & $\begin{array}{c}-0.0241 * * \\
(0.0075)\end{array}$ \\
\hline Wave 6 & $\begin{array}{c}0.0276^{* * * *} \\
(0.0068)\end{array}$ & $\begin{array}{c}-0.0366^{* * *} \\
(0.0075)\end{array}$ & $\begin{array}{c}-0.0369^{* * *} \\
(0.0075)\end{array}$ \\
\hline Wave 7 & $\begin{array}{l}0.0155^{*} \\
(0.0070)\end{array}$ & $\begin{array}{c}-0.0805^{* * *} * \\
(0.0076)\end{array}$ & $\begin{array}{c}-0.0807 * * * \\
(0.0076)\end{array}$ \\
\hline Wave 8 & $\begin{array}{c}0.0231 * * \\
(0.0072)\end{array}$ & $\begin{array}{c}-0.0576^{* * * *} \\
(0.0078)\end{array}$ & $\begin{array}{c}-0.0578 * * * \\
(0.0078)\end{array}$ \\
\hline Wave 9 & $\begin{array}{c}0.0398 * * * \\
(0.0074)\end{array}$ & $\begin{array}{c}-0.0657 * * * \\
(0.0080)\end{array}$ & $\begin{array}{c}-0.0662 * * * \\
(0.0080)\end{array}$ \\
\hline Wave 10 & $\begin{array}{c}0.0275 * * * \\
(0.0075)\end{array}$ & $\begin{array}{c}-0.0743^{* * *} \\
(0.0082)\end{array}$ & $\begin{array}{c}-0.0746^{* * *} \\
(0.0082)\end{array}$ \\
\hline Wave 11 & $\begin{array}{c}0.0012 \\
(0.0077)\end{array}$ & $\begin{array}{c}-0.0604 * * * \\
(0.0082)\end{array}$ & $\begin{array}{c}-0.0604 * * * \\
(0.0082)\end{array}$ \\
\hline Wave 12 & $\begin{array}{c}0.0247 * * \\
(0.0081)\end{array}$ & $\begin{array}{c}-0.0803 * * * \\
(0.0086)\end{array}$ & $\begin{array}{c}-0.0806^{* * *} \\
(0.0086)\end{array}$ \\
\hline Constant & $\begin{array}{c}0.2298^{*} * * \\
(0.0187)\end{array}$ & $\begin{array}{c}0.4884 * * * \\
(0.0176)\end{array}$ & $\begin{array}{c}0.4855^{*} * * \\
(0.0176)\end{array}$ \\
\hline $\begin{array}{l}\text { Observations } \\
\mathrm{N}\end{array}$ & $\begin{array}{l}77,294 \\
15,863\end{array}$ & $\begin{array}{l}77,294 \\
15,863\end{array}$ & $\begin{array}{l}77,294 \\
15,863\end{array}$ \\
\hline
\end{tabular}

Source: PASS, Welle 12 v1 (DOI: 10.5164/IAB.PASS-SUF0618.de.en.v1), own calculation.

Note: Clustered standard errors in parentheses; ${ }^{*} p<0.05,{ }^{* *} p<0.01,{ }^{* * *} p<0.001$, standard errors clustered by individual. 
The Intervening Role of Social Integration in the Effect of Education on Subjective Mental Health

Table A.15: FE results for the effect of mediators on overall health status including control variables

\begin{tabular}{|c|c|c|c|c|}
\hline & At least good overall health & At least good overall health & At least good overall health & At least good overall health \\
\hline $\begin{array}{l}\text { Level of social } \\
\text { integration }\end{array}$ & $\begin{array}{l}0.00127 \\
(0.0026)\end{array}$ & & & \\
\hline Married or cohabited & & $\begin{array}{l}-0.0126 \\
(0.0096)\end{array}$ & & \\
\hline $\begin{array}{l}\text { Number of close friends } \\
\text { and relatives outside the } \\
\text { household }(\ln )\end{array}$ & & & $\begin{array}{l}0.0139^{* * *} \\
(0.0037)\end{array}$ & \\
\hline $\begin{array}{l}\text { Membership in a } \\
\text { voluntary association }\end{array}$ & & & & $\begin{array}{l}0.00621 \\
(0.0050)\end{array}$ \\
\hline Years of education & $\begin{array}{l}0.0180^{*} \\
(0.0074)\end{array}$ & $\begin{array}{l}0.0181^{*} \\
(0.0074)\end{array}$ & $\begin{array}{l}0.0179^{*} \\
(0.0074)\end{array}$ & $\begin{array}{l}0.0179^{*} \\
(0.0074)\end{array}$ \\
\hline $\begin{array}{l}\text { Age group (ref.: } 30-39) \\
\text { 40-49 }\end{array}$ & $\begin{array}{c}-0.000630 \\
(0.0094)\end{array}$ & $\begin{array}{l}-0.000626 \\
(0.0094)\end{array}$ & $\begin{array}{l}-0.0000830 \\
(0.0094)\end{array}$ & $\begin{array}{c}-0.000694 \\
(0.0094)\end{array}$ \\
\hline $50-60$ & $\begin{array}{l}-0.0112 \\
(0.0131)\end{array}$ & $\begin{array}{l}-0.0111 \\
(0.0131)\end{array}$ & $\begin{array}{l}-0.0109 \\
(0.0131)\end{array}$ & $\begin{array}{l}-0.0112 \\
(0.0131)\end{array}$ \\
\hline West Germany & $\begin{array}{l}-0.0212 \\
(0.0324)\end{array}$ & $\begin{array}{l}-0.0199 \\
(0.0323)\end{array}$ & $\begin{array}{l}-0.0215 \\
(0.0324)\end{array}$ & $\begin{array}{l}-0.0208 \\
(0.0323)\end{array}$ \\
\hline Number of children & $\begin{array}{l}-0.0138^{* * * *} \\
(0.0041)\end{array}$ & $\begin{array}{l}-0.0134^{* *} \\
(0.0041)\end{array}$ & $\begin{array}{l}-0.0138^{* * *} \\
(0.0041)\end{array}$ & $\begin{array}{l}-0.0137^{* * *} \\
(0.0041)\end{array}$ \\
\hline \multicolumn{5}{|l|}{$\begin{array}{l}\text { Survey wave (ref.: wave } \\
\text { 1) }\end{array}$} \\
\hline Wave 2 & $\begin{array}{l}-0.0179^{*} \\
(0.0072)\end{array}$ & $\begin{array}{l}-0.0180^{*} \\
(0.0072)\end{array}$ & $\begin{array}{l}-0.0175^{*} \\
(0.0072)\end{array}$ & $\begin{array}{l}-0.0179^{*} \\
(0.0072)\end{array}$ \\
\hline Wave 3 & $\begin{array}{l}-0.0432^{* * *} \\
(0.0074)\end{array}$ & $\begin{array}{l}-0.0433^{* * *} \\
(0.0074)\end{array}$ & $\begin{array}{l}-0.0416^{* * *} \\
(0.0075)\end{array}$ & $\begin{array}{l}-0.0432^{* * *} \\
(0.0074)\end{array}$ \\
\hline Wave 4 & $\begin{array}{c}-0.0355^{* * *} \\
(0.0079)\end{array}$ & $\begin{array}{c}-0.0356^{* * *} \\
(0.0079)\end{array}$ & $\begin{array}{l}-0.0340^{* * *} \\
(0.0079)\end{array}$ & $\begin{array}{l}-0.0357^{* * *} \\
(0.0079)\end{array}$ \\
\hline Wave 5 & $\begin{array}{l}-0.0455^{* * *} \\
(0.0082)\end{array}$ & $\begin{array}{l}-0.0456^{* * * *} \\
(0.0082)\end{array}$ & $\begin{array}{l}-0.0433^{* * * *} \\
(0.0082)\end{array}$ & $\begin{array}{l}-0.0457^{* * * *} \\
(0.0082)\end{array}$ \\
\hline Wave 6 & $\begin{array}{c}-0.0620^{* * *} \\
(0.0084)\end{array}$ & $\begin{array}{l}-0.0621^{* * *} \\
(0.0084)\end{array}$ & $\begin{array}{l}-0.0599^{* * *} \\
(0.0084)\end{array}$ & $\begin{array}{l}-0.0622^{* * *} \\
(0.0084)\end{array}$ \\
\hline Wave 7 & $\begin{array}{l}-0.112^{* * *} \\
(0.0087)\end{array}$ & $\begin{array}{l}-0.112^{* * *} \\
(0.0087)\end{array}$ & $\begin{array}{l}-0.109^{* * * *} \\
(0.0087)\end{array}$ & $\begin{array}{l}-0.112^{* * *} \\
(0.0087)\end{array}$ \\
\hline Wave 8 & $\begin{array}{c}-0.0933^{* * *} \\
(0.0090)\end{array}$ & $\begin{array}{c}-0.0935^{* * *} \\
(0.0090)\end{array}$ & $\begin{array}{l}-0.0911^{* * *} \\
(0.0090)\end{array}$ & $\begin{array}{c}-0.0936^{* * *} \\
(0.0090)\end{array}$ \\
\hline Wave 9 & $\begin{array}{l}-0.109^{* * *} \\
(0.0095)\end{array}$ & $\begin{array}{l}-0.109^{* * *} \\
(0.0095)\end{array}$ & $\begin{array}{l}-0.107^{* * * *} \\
(0.0095)\end{array}$ & $\begin{array}{l}-0.109^{* * *} \\
(0.0095)\end{array}$ \\
\hline Wave 10 & $\begin{array}{l}-0.124^{* * *} \\
(0.0099)\end{array}$ & $\begin{array}{l}-0.124^{* * *} \\
(0.0099)\end{array}$ & $\begin{array}{l}-0.122^{* * * *} \\
(0.0099)\end{array}$ & $\begin{array}{l}-0.124^{* * *} \\
(0.0099)\end{array}$ \\
\hline Wave 11 & $\begin{array}{l}-0.119^{* * *} \\
(0.0103)\end{array}$ & $\begin{array}{l}-0.119^{* * *} \\
(0.0103)\end{array}$ & $\begin{array}{l}-0.116^{* * *} \\
(0.0103)\end{array}$ & $\begin{array}{l}-0.119^{* * *} \\
(0.0103)\end{array}$ \\
\hline Wave 12 & $\begin{array}{c}-0.144^{* * * *} \\
(0.0109)\end{array}$ & $\begin{array}{c}-0.144^{* * *} \\
(0.0109)\end{array}$ & $\begin{array}{l}-0.141^{* * * *} \\
(0.0109)\end{array}$ & $\begin{array}{l}-0.144^{* * *} \\
(0.0109)\end{array}$ \\
\hline Constant & $\begin{array}{l}0.336^{* * *} \\
(0.0941)\end{array}$ & $\begin{array}{l}0.344^{* * * *} \\
(0.0939)\end{array}$ & $\begin{array}{l}0.311^{* * * *} \\
(0.0943)\end{array}$ & $\begin{array}{l}0.337^{* * * *} \\
(0.0939)\end{array}$ \\
\hline $\begin{array}{l}\text { Observations } \\
N\end{array}$ & $\begin{array}{l}77,294 \\
15,863 \\
\end{array}$ & $\begin{array}{l}77,294 \\
15,863 \\
\end{array}$ & $\begin{array}{l}77,294 \\
15,863 \\
\end{array}$ & $\begin{array}{l}77,294 \\
15,863 \\
\end{array}$ \\
\hline
\end{tabular}

Source: PASS, Welle 12 v1 (DOI: 10.5164/IAB.PASS-SUF0618.de.en.v1), own calculation.

Note: Clustered standard errors in parentheses; ${ }^{*} p<0.05,{ }^{* *} p<0.01,{ }^{* * *} p<0.001$, standard errors clustered by individual. 


\section{Appendix $B$}

Table B.1: RE results for the mediation of the emotional support in the effect of education on mental health including control variables

\begin{tabular}{|c|c|c|c|}
\hline & Emotional support & $\begin{array}{c}\text { At least good mental } \\
\text { health }\end{array}$ & $\begin{array}{c}\text { At least good mental } \\
\text { health }\end{array}$ \\
\hline Years of education & $\begin{array}{l}0.00148 \\
(0.0009)\end{array}$ & $\begin{array}{l}0.00423 \\
(0.0026)\end{array}$ & $\begin{array}{l}0.00420 \\
(0.0026)\end{array}$ \\
\hline Emotional support & & & $\begin{array}{c}0.0186 \\
(0.0376)\end{array}$ \\
\hline \multicolumn{4}{|c|}{ Socio-economic background (ref.: parents with low levels of education) } \\
\hline Medium level of education & $\begin{array}{c}0.0017 \\
(0.0049)\end{array}$ & $\begin{array}{l}-0.0207 \\
(0.0172)\end{array}$ & $\begin{array}{l}-0.0207 \\
(0.0172)\end{array}$ \\
\hline Higher level of education & $\begin{array}{c}0.0001 \\
(0.0055)\end{array}$ & $\begin{array}{l}-0.0074 \\
(0.0193)\end{array}$ & $\begin{array}{l}-0.0074 \\
(0.0193)\end{array}$ \\
\hline Other degree & $\begin{array}{c}0.0006 \\
(0.0072)\end{array}$ & $\begin{array}{c}0.0208 \\
(0.0222)\end{array}$ & $\begin{array}{c}0.0207 \\
(0.0222)\end{array}$ \\
\hline $\begin{array}{l}\text { Age group (ref.: } 30-39) \\
40-49\end{array}$ & $\begin{array}{c}-0.0105^{*} \\
(0.0042)\end{array}$ & $\begin{array}{l}-0.0161 \\
(0.0147)\end{array}$ & $\begin{array}{l}-0.0159 \\
(0.0147)\end{array}$ \\
\hline $50-60$ & $\begin{array}{l}-0.0123 * \\
(0.0049)\end{array}$ & $\begin{array}{l}-0.0343^{*} \\
(0.0160)\end{array}$ & $\begin{array}{l}-0.0340 * \\
(0.0160)\end{array}$ \\
\hline West Germany & $\begin{array}{c}0.0036 \\
(0.0042)\end{array}$ & $\begin{array}{l}-0.0370 * \\
(0.0145)\end{array}$ & $\begin{array}{c}-0.0371 * \\
(0.0145)\end{array}$ \\
\hline Female & $\begin{array}{c}0.0136 * * * \\
(0.0041)\end{array}$ & $\begin{array}{l}-0.1141 * * * \\
(0.0124)\end{array}$ & $\begin{array}{l}-0.1143 * * * \\
(0.0124)\end{array}$ \\
\hline Migration background & $\begin{array}{c}-0.0425 * * * \\
(0.0072)\end{array}$ & $\begin{array}{c}0.0312 \\
(0.0165)\end{array}$ & $\begin{array}{c}0.0320 \\
(0.0166)\end{array}$ \\
\hline $\begin{array}{l}\text { Sample affiliation (ref.: genera } \\
\text { PASS welfare benefit } \\
\text { recipients sample }\end{array}$ & $\begin{array}{l}\text { ation sample) } \\
-0.0107 * * \\
(0.0041)\end{array}$ & $\begin{array}{c}-0.1159 * * * \\
(0.0134)\end{array}$ & $\begin{array}{c}-0.1157 * * * \\
(0.0134)\end{array}$ \\
\hline Number of children & $\begin{array}{l}-0.0011 \\
(0.0017)\end{array}$ & $\begin{array}{l}0.0128^{*} \\
(0.0051)\end{array}$ & $\begin{array}{l}0.0128 * \\
(0.0051)\end{array}$ \\
\hline $\begin{array}{l}\text { Survey Wave (ref.: wave 5) } \\
\text { Wave } 3\end{array}$ & $\begin{array}{l}-0.0060 \\
(0.0032)\end{array}$ & $\begin{array}{c}-0.0243 * * \\
(0.0091)\end{array}$ & $\begin{array}{c}-0.0242 * * \\
(0.0091)\end{array}$ \\
\hline Constant & $\begin{array}{c}0.9745 * * * \\
(0.0138) \\
\end{array}$ & $\begin{array}{c}0.7647 * * * \\
(0.0398) \\
\end{array}$ & $\begin{array}{c}0.7465^{* * * *} \\
(0.0539) \\
\end{array}$ \\
\hline $\begin{array}{l}\text { Observations } \\
\mathrm{N}\end{array}$ & $\begin{array}{l}7,517 \\
3,851 \\
\end{array}$ & $\begin{array}{l}7,517 \\
3,851 \\
\end{array}$ & $\begin{array}{l}7,517 \\
3,851 \\
\end{array}$ \\
\hline
\end{tabular}

Source: PASS, Welle 12 v1 (DOI: 10.5164/IAB.PASS-SUF0618.de.en.v1), own calculation; only individuals observed in waves 3 and 5 .

Note: Clustered standard errors by individuals in parentheses; ${ }^{*} p<0.05,{ }^{* *} p<0.01,{ }^{* * *} p<0.001$. 
The Intervening Role of Social Integration in the Effect of Education on Subjective Mental Health

Table B.2: RE results for the mediation of work-related support in the effect of education on mental health including control variables

\begin{tabular}{|c|c|c|c|}
\hline & Work-related support & $\begin{array}{l}\text { At least good mental } \\
\text { health }\end{array}$ & $\begin{array}{c}\text { At least good mental } \\
\text { health }\end{array}$ \\
\hline Years of education & $\begin{array}{l}0.0036^{*} \\
(0.0016)\end{array}$ & $\begin{array}{c}0.0042 \\
(0.0026)\end{array}$ & $\begin{array}{c}0.0041 \\
(0.0026)\end{array}$ \\
\hline Work-related support & & & $\begin{array}{c}0.0361 \\
(0.0192)\end{array}$ \\
\hline \multicolumn{4}{|c|}{ Socio-economic background (ref.: parents with low levels of education) } \\
\hline Medium level of education & $\begin{array}{c}0.0069 \\
(0.0099)\end{array}$ & $\begin{array}{l}-0.0207 \\
(0.0172)\end{array}$ & $\begin{array}{l}-0.0209 \\
(0.0172)\end{array}$ \\
\hline Higher level of education & $\begin{array}{c}0.0187 \\
(0.0108)\end{array}$ & $\begin{array}{l}-0.0074 \\
(0.0193)\end{array}$ & $\begin{array}{l}-0.0081 \\
(0.0193)\end{array}$ \\
\hline Other degree & $\begin{array}{l}-0.0263 \\
(0.0152)\end{array}$ & $\begin{array}{c}0.0208 \\
(0.0222)\end{array}$ & $\begin{array}{c}0.0217 \\
(0.0222)\end{array}$ \\
\hline $\begin{array}{l}\text { Age group (ref.: } 30-39) \\
40-49\end{array}$ & $\begin{array}{c}-0.0313 * * * \\
(0.0079)\end{array}$ & $\begin{array}{l}-0.0161 \\
(0.0147)\end{array}$ & $\begin{array}{l}-0.0149 \\
(0.0147)\end{array}$ \\
\hline $50-60$ & $\begin{array}{c}-0.0854 * * * \\
(0.0097)\end{array}$ & $\begin{array}{l}-0.0343 * \\
(0.0160)\end{array}$ & $\begin{array}{l}-0.0312 \\
(0.0160)\end{array}$ \\
\hline West Germany & $\begin{array}{c}0.0044 \\
(0.0087)\end{array}$ & $\begin{array}{l}-0.0370^{*} \\
(0.0145)\end{array}$ & $\begin{array}{c}-0.0372 * \\
(0.0145)\end{array}$ \\
\hline Female & $\begin{array}{c}0.0112 \\
(0.0077)\end{array}$ & $\begin{array}{c}-0.1141 * * * \\
(0.0124)\end{array}$ & $\begin{array}{c}-0.1145^{* * *} \\
(0.0124)\end{array}$ \\
\hline Migration background & $\begin{array}{c}-0.1273 * * * \\
(0.0128)\end{array}$ & $\begin{array}{c}0.0312 \\
(0.0165)\end{array}$ & $\begin{array}{l}0.0358 * \\
(0.0167)\end{array}$ \\
\hline \multicolumn{4}{|l|}{$\begin{array}{l}\text { Sample affiliation (ref.: general } \\
\text { population sample) }\end{array}$} \\
\hline $\begin{array}{l}\text { PASS welfare benefit } \\
\text { recipients sample }\end{array}$ & $\begin{array}{l}-0.0205^{*} \\
(0.0082)\end{array}$ & $\begin{array}{c}-0.1159 * * * \\
(0.0134)\end{array}$ & $\begin{array}{c}-0.1152 * * * \\
(0.0134)\end{array}$ \\
\hline Number of children & $\begin{array}{l}-0.0059 \\
(0.0033)\end{array}$ & $\begin{array}{l}0.0128 * \\
(0.0051)\end{array}$ & $\begin{array}{c}0.0130 * * \\
(0.0050)\end{array}$ \\
\hline $\begin{array}{l}\text { Survey Wave (ref.: wave 5) } \\
\text { Wave } 3\end{array}$ & $\begin{array}{c}-0.0351 * * * \\
(0.0059)\end{array}$ & $\begin{array}{c}-0.0243 * * \\
(0.0091)\end{array}$ & $\begin{array}{l}-0.0231 * \\
(0.0092)\end{array}$ \\
\hline Constant & $\begin{array}{c}0.9505 * * * \\
(0.0257)\end{array}$ & $\begin{array}{c}0.7647 * * * \\
(0.0398)\end{array}$ & $\begin{array}{c}0.7303 * * * \\
(0.0439)\end{array}$ \\
\hline $\begin{array}{l}\text { Observations } \\
\mathrm{N}\end{array}$ & $\begin{array}{l}7,517 \\
3,851 \\
\end{array}$ & $\begin{array}{l}7,517 \\
3,851 \\
\end{array}$ & $\begin{array}{l}7,517 \\
3,851 \\
\end{array}$ \\
\hline
\end{tabular}

Source: PASS, Welle 12 v1 (DOI: 10.5164/IAB.PASS-SUF0618.de.en.v1), own calculation; only individuals observed in waves 3 and 5.

Note: Clustered standard errors by individuals in parentheses; ${ }^{*} p<0.05,{ }^{* *} p<0.01,{ }^{* * *} p<0.001$. 
The Intervening Role of Social Integration in the Effect of Education on Subjective Mental Health

Table B.3: RE results for the mediation of financial support in the effect of education on mental health including control variables

\begin{tabular}{|c|c|c|c|}
\hline & Financial Support & $\begin{array}{l}\text { At least good mental } \\
\text { health }\end{array}$ & $\begin{array}{l}\text { At least good mental } \\
\text { health }\end{array}$ \\
\hline Years of education & $\begin{array}{c}0.0186^{* * *} \\
(0.0019)\end{array}$ & $\begin{array}{c}0.0042 \\
(0.0026)\end{array}$ & $\begin{array}{c}0.0030 \\
(0.0026)\end{array}$ \\
\hline Financial Support & & & $\begin{array}{c}0.0671 * * * \\
(0.0150)\end{array}$ \\
\hline \multicolumn{4}{|c|}{$\begin{array}{l}\text { Socio-economic background (ref.: parents with low levels of } \\
\text { education) }\end{array}$} \\
\hline Medium level of education & $\begin{array}{l}0.0323^{*} \\
(0.0135)\end{array}$ & $\begin{array}{l}-0.0207 \\
(0.0172)\end{array}$ & $\begin{array}{l}-0.0228 \\
(0.0172)\end{array}$ \\
\hline Higher level of education & $\begin{array}{l}0.0325^{*} \\
(0.0143)\end{array}$ & $\begin{array}{l}-0.0074 \\
(0.0193)\end{array}$ & $\begin{array}{l}-0.0096 \\
(0.0192)\end{array}$ \\
\hline Other degree & $\begin{array}{l}-0.0225 \\
(0.0212)\end{array}$ & $\begin{array}{c}0.0208 \\
(0.0222)\end{array}$ & $\begin{array}{c}0.0223 \\
(0.0222)\end{array}$ \\
\hline $\begin{array}{l}\text { Age group (ref.: } 30-39) \\
40-49\end{array}$ & $\begin{array}{l}-0.0104 \\
(0.0123)\end{array}$ & $\begin{array}{l}-0.0161 \\
(0.0147)\end{array}$ & $\begin{array}{l}-0.0153 \\
(0.0147)\end{array}$ \\
\hline $50-60$ & $\begin{array}{l}-0.0152 \\
(0.0133)\end{array}$ & $\begin{array}{l}-0.0343^{*} \\
(0.0160)\end{array}$ & $\begin{array}{l}-0.0332 * \\
(0.0160)\end{array}$ \\
\hline West Germany & $\begin{array}{c}0.0391 * * \\
(0.0126)\end{array}$ & $\begin{array}{l}-0.0370^{*} \\
(0.0145)\end{array}$ & $\begin{array}{l}-0.0397 * * \\
(0.0145)\end{array}$ \\
\hline Female & $\begin{array}{c}0.0073 \\
(0.0104)\end{array}$ & $\begin{array}{c}-0.1141 * * * \\
(0.0124)\end{array}$ & $\begin{array}{c}-0.1146 * * * \\
(0.0124)\end{array}$ \\
\hline Migration background & $\begin{array}{r}-0.0299 * \\
(0.0150)\end{array}$ & $\begin{array}{c}0.0312 \\
(0.0165)\end{array}$ & $\begin{array}{l}0.0332 * \\
(0.0165)\end{array}$ \\
\hline BA sample & $\begin{array}{c}-0.1766 * * * \\
(0.0110)\end{array}$ & $\begin{array}{c}-0.1159 * * * \\
(0.0134)\end{array}$ & $\begin{array}{c}-0.1041 * * * \\
(0.0136)\end{array}$ \\
\hline Number of children & $\begin{array}{l}-0.0027 \\
(0.0043)\end{array}$ & $\begin{array}{l}0.0128 * \\
(0.0051)\end{array}$ & $\begin{array}{l}0.0130 * * \\
(0.0050)\end{array}$ \\
\hline $\begin{array}{l}\text { Survey Wave (ref.: wave 5) } \\
\quad \text { Wave } 3\end{array}$ & $\begin{array}{c}-0.0516 * * * \\
(0.0072)\end{array}$ & $\begin{array}{c}-0.0243 * * \\
(0.0091)\end{array}$ & $\begin{array}{r}-0.0209 * \\
(0.0092)\end{array}$ \\
\hline Constant & $\begin{array}{c}0.6639 * * * \\
(0.0320) \\
\end{array}$ & $\begin{array}{c}0.7647 * * * \\
(0.0398)\end{array}$ & $\begin{array}{c}0.7200 * * * \\
(0.0410)\end{array}$ \\
\hline $\begin{array}{l}\text { Observations } \\
\mathrm{N}\end{array}$ & $\begin{array}{l}7,517 \\
3,851\end{array}$ & $\begin{array}{l}7,517 \\
3,851\end{array}$ & $\begin{array}{l}7,517 \\
3,851 \\
\end{array}$ \\
\hline
\end{tabular}

Source: PASS, Welle 12 v1 (DOI: 10.5164/IAB.PASS-SUF0618.de.en.v1), own calculation; only individuals observed in waves 3 and 5.

Note: Clustered standard errors by individuals in parentheses; ${ }^{*} p<0.05,{ }^{* *} p<0.01,{ }^{* * *} p<0.001$, standard errors clustered by individual. 
Table B.4: The total, direct and indirect effects of education for social support

\begin{tabular}{lcccc}
\hline Mediator & $\begin{array}{c}\text { Total effect of } \\
\text { education on } \\
\text { mental health } \\
\boldsymbol{\beta}_{\mathbf{1}}\end{array}$ & $\begin{array}{c}\text { Direct effect of } \\
\text { education on } \\
\text { mental health } \\
\boldsymbol{\beta}_{\mathbf{2}}\end{array}$ & $\begin{array}{c}\text { Indirect Effect } \\
\boldsymbol{\beta}_{\mathbf{1}}-\boldsymbol{\beta}_{\mathbf{2}}\end{array}$ & $\begin{array}{c}\text { Percent of total } \\
\text { effect }\end{array}$ \\
\hline Emotional support & 0.0042 & 0.00420 & $\frac{\left(\boldsymbol{\beta}_{\mathbf{1}}-\boldsymbol{\gamma}_{\mathbf{1}}\right)}{\boldsymbol{\beta}_{\mathbf{1}}} \times \mathbf{1 0 0}$ \\
\hline Work-related support & $(0.0026)$ & $(0.0026)$ & $7.14 \%$ \\
\hline Financial support & 0.0042 & 0.0041 & 0.0001 & $2.38 \%$ \\
\hline
\end{tabular}

Source: PASS, Welle 12 v1 (DOI: 10.5164/IAB.PASS-SUF0618.de.en.v1), own calculation; N=3,851, only individuals observed in waves 3 and 5 .

Note: Clustered standard errors in parentheses; ${ }^{*} p<0.05,{ }^{* *} p<0.01,{ }^{* * *} p<0.001$, standard errors clustered by individual.

${ }^{1}$ Small differences in the calculation of the total effect based on the indirect and direct effects reported and the estimation results presented in column 1 are due to rounding errors.

Table B.5: FE results for the effect of social support on mental health including control variables

\begin{tabular}{|c|c|c|c|}
\hline & $\begin{array}{c}\text { At least good mental } \\
\text { health }\end{array}$ & $\begin{array}{c}\text { At least good mental } \\
\text { health }\end{array}$ & $\begin{array}{c}\text { At least good mental } \\
\text { health }\end{array}$ \\
\hline Emotional Support & $\begin{array}{c}0.00637 \\
(0.12)\end{array}$ & & \\
\hline Work-related support & & $\begin{array}{c}0.0183 \\
(0.68)\end{array}$ & \\
\hline Financial support & & & $\begin{array}{c}0.0511^{*} \\
(2.32)\end{array}$ \\
\hline $\begin{array}{l}\text { Age group (ref.: } 30-39) \\
\text { 40-49 }\end{array}$ & $\begin{array}{l}-0.0365 \\
(-1.08)\end{array}$ & $\begin{array}{l}-0.0359 \\
(-1.07)\end{array}$ & $\begin{array}{l}-0.0374 \\
(-1.11)\end{array}$ \\
\hline $50-60$ & $\begin{array}{l}-0.0944 \\
(-1.96)\end{array}$ & $\begin{array}{l}-0.0935 \\
(-1.94)\end{array}$ & $\begin{array}{c}-0.0977^{*} \\
(-2.03)\end{array}$ \\
\hline West Germany & $\begin{array}{l}0.206 \\
(1.22)\end{array}$ & $\begin{array}{l}0.211 \\
(1.25)\end{array}$ & $\begin{array}{l}0.212 \\
(1.26)\end{array}$ \\
\hline Number of own children & $\begin{array}{c}0.0151 \\
(0.98)\end{array}$ & $\begin{array}{c}0.0152 \\
(0.99)\end{array}$ & $\begin{array}{c}0.0141 \\
(0.91)\end{array}$ \\
\hline $\begin{array}{l}\text { Survey Wave (ref.: wave } \\
\text { Wave } 3\end{array}$ & $\begin{array}{c}-0.0293^{* *} \\
(-2.93)\end{array}$ & $\begin{array}{c}-0.0287^{* *} \\
(-2.86)\end{array}$ & $\begin{array}{c}-0.0271^{* *} \\
(-2.69)\end{array}$ \\
\hline Constant & $\begin{array}{l}0.542^{* * *} \\
(3.94)\end{array}$ & $\begin{array}{l}0.528^{* * *} \\
(4.10)\end{array}$ & $\begin{array}{l}0.505^{* * *} \\
(3.96)\end{array}$ \\
\hline $\begin{array}{l}\text { Observations } \\
\mathrm{N}\end{array}$ & $\begin{array}{l}7,517 \\
3,851\end{array}$ & $\begin{array}{l}7,517 \\
3,851\end{array}$ & $\begin{array}{l}7,517 \\
3,851\end{array}$ \\
\hline
\end{tabular}

Source: PASS, Welle 12 v1 (DOI: 10.5164/IAB.PASS-SUF0618.de.en.v1), own calculation; only individuals observed in waves 3 and 5 .

Note: Clustered standard errors in parentheses; ${ }^{*} p<0.05,{ }^{* *} p<0.01,{ }^{* * *} p<0.001$, standard errors clustered by individual. 